\title{
Article \\ Improving Hill Farming: From Maize Monocropping to Alternative Cropping Systems in the Thai Highlands
}

\author{
Chiranan Senanuch ${ }^{1,2}$, Takuji W. Tsusaka ${ }^{1,3, *(\mathbb{C}}$, Avishek Datta ${ }^{3}$ and Nophea Sasaki ${ }^{1}$ (]) \\ 1 Department of Development and Sustainability, Asian Institute of Technology, Pathum Thani 12120, Thailand; \\ senanuch.c@alro.go.th (C.S.); nopheas@ait.ac.th (N.S.) \\ 2 Agricultural Land Reform Office, Ministry of Agriculture and Cooperatives, Bangkok 10200, Thailand \\ 3 Department of Food, Agriculture and Bioresources, Asian Institute of Technology, Pathum Thani 12120, \\ Thailand; datta@ait.ac.th \\ * Correspondence: takuji@ait.ac.th; Tel.: +1-646-8068323
}

Citation: Senanuch, C.; Tsusaka, T.W.; Datta, A.; Sasaki, N. Improving Hill Farming: From Maize Monocropping to Alternative Cropping Systems in the Thai Highlands. Land 2022, 11, 132. https://doi.org/10.3390/ land11010132

Academic Editor: Purushothaman Chirakkuzhyil Abhilash

Received: 4 December 2021

Accepted: 10 January 2022

Published: 15 January 2022

Publisher's Note: MDPI stays neutral with regard to jurisdictional claims in published maps and institutional affiliations.

Copyright: (C) 2022 by the authors. Licensee MDPI, Basel, Switzerland. This article is an open access article distributed under the terms and conditions of the Creative Commons Attribution (CC BY) license (https:// creativecommons.org/licenses/by/ $4.0 /)$.

\begin{abstract}
Lately, the Hill Pond Rice System (HPRS) is being promoted as a form of alternative farming systems in selected northern provinces of Thailand, in which the land conversion is designed to maximize rainwater harvesting in farmland consisting of forest trees, water reservoirs, paddy fields, and high-value crop cultivation to serve environmental and livelihood needs. This study employed the double-hurdle model and the tobit technique to investigate the farm-level factors associated with land conversion from maize monocropping to the HPRS using primary data collected from 253 households in Nan, Chiang Mai, Tak, and Lampang Provinces. It was found that education, farming knowledge, understanding benefits of the HPRS, access to water sources, access to advis, and workforce sharing raised the likelihood and extent of farmland conversion into the HPRS. In contrast, perceived complexity of the HPRS, experiences with negative shocks, and land tenure security lowered the likelihood and extent of land conversion. The findings suggest that on-farm collective action should be promoted to mitigate labor constraints in implementation and that access to equipment should be enhanced through HPRS advisors' visits.
\end{abstract}

Keywords: integrated farming system; sustainable agricultural practices; technology adoption; Hill Pond Rice System (HPRS); upland farming; rice-fish system; agroforestry; double-hurdle model; tobit

\section{Introduction}

Over the past several decades, the global need for boosting food production has brought incremental modernization of agriculture in developing countries toward agricultural intensification with increased use of external inputs, such as improved seeds, synthetic pesticides and fertilizers, mechanization, and irrigation facilities [1-3] as well as traditional land expansion [4,5], resulting in doubled or tripled land productivity and reduced food security concerns [6-8].

However, the changes in cropping patterns and production practices in favor of intensive monocropping systems gave rise to outbreaks of pests, weed, and plant diseases, which were treated with increased use of external chemicals. The intensive use of pesticides poses a health threat to both farmers and consumers, as well as disruption to ecosystems [4,5,9-12]. Moreover, repeated cultivation of the same crop in the same parcels results in the extraction of particular nutrients from soil, leading to intensive use of synthetic fertilizer to compensate for the nutrient loss [13-16]. Therefore, intensive monocropping practices create negative externalities when these agrochemicals eventually make their way into groundwater or become airborne pollutants, affecting the surrounding environments [17-19]. Moreover, use of mechanical soil tillage disrupts the natural composition of soil and causes soil erosion, compaction, nutrient runoff, groundwater pollution and eutrophication, and biodiversity loss, which is the underlying cause of ecosystem degradation [20-23]. Besides, these changes contribute to the aggravation of climate change 
as degraded vegetation reduces its carbon storage capacity and releases greenhouse gases into the atmosphere [24]. Deforestation and forest degradation due to farmland expansion also have adverse effects on recycling rainwater, regulation of wind speeds, and rising temperature [25-27]. Crops and livestock yields are directly affected by harsh climatic events [28-30].

While the resource base sustaining agriculture has deteriorated, a growing number of innovations have emerged for farming systems that are more sustainable environmentally, socially, and economically [31-33]. For instance, conservation agriculture aims to minimize soil disturbances, maintain soil cover, and promote cropping diversity according to local conditions and limitations [34]. Agroecological systems consist of environmentally friendly methods of farming that help improve or maintain soil fertility and protect against degradation of resources through biological and ecological processes while optimizing production $[31,33,35]$. Other improved farming practices include organic agriculture, minimum use of synthetic fertilizer, crop rotation, multiple cropping, crop-livestock integration, and agroforestry, among other things [15,36-43].

As is the case with many agrarian economies, Thailand's agricultural sector has been in transition from subsistence farming to industrial agriculture [44]. With the increasing integration of inputs and outputs into the market mechanism, farmers' livelihoods tended to hinge on external inputs, such as machinery, fertilizer, improved seeds, pesticides, irrigation, and hired labor [45]. The downsides of unsustainable practices are particularly pronounced in the northern highlands of the country. Much of the northern region lies in the mountainous landscape, where intensive monocropping agriculture occupies a large part of the forest areas, particularly maize (Zea mays. L.) production for fodder markets [11,46], which typically entails mechanical soil tillage [47]. As these areas are located in the upstream of major rivers, the degradation of soil and water resources has adversely affected the livelihoods of the downstream population as well, adding to the externalities [48].

To boost the resilience and adaptive capacity to environmental changes in the context of the Sustainable Development Goals (SDGs), a set of alternative farming systems encompassing organic farming, natural farming, integrated farming, New Theory farming, and agroforestry systems have been introduced to rural farmers in Thailand in various manners [49-51]. One of the alternative land management systems that is being promoted by the government for the northern dry highlands is the Hill Pond Rice system (HPRS) [52]. The HPRS follows the philosophy of sufficiency economy (SEP) [53], where the farm field is divided into four principal sections, namely, (i) a hill area for forest plantation and conservation, (ii) a pond for rainwater collection and aquaculture, (iii) an organic paddy field for household consumption and supplementary aquaculture, and (iv) a field for cash crops [54]. This farming system is based on precisely calculated land allocation and resource use, according to the altitude of the terrain, which maximizes rainwater harvesting for irrigating crops all year round [54]. While the HPRS is intended for conservation purposes, the cash crop section caters to income generation for the households. In other words, the HPRS integrates water resource management, organic rice production for consumption, cash crop cultivation, aquaculture, and agroforestry, which is expected to help enhance farmers resilience and catalyze reforestation [50].

Although concerned authorities and agencies have provided extension services and training programs in coordination with farmers in selected areas to date, quite a number of trained farmers have remained reluctant to convert their current cropping systems into the HPRS. While the extension efforts need to be focused on dissemination of the alternative farming practices, success would depend on the understanding of farm-level factors associated with the uptake of the HPRS.

Literature studied factors associated with the adoption of improved farming practices, such as organic farming [55-57], integrated pest management [58], and sustainable land management [51]. In the highlands of developing countries, various studies analyzed factors influencing the adoption of soil and water conservation practices [59-64]. 
Empirical evidence suggests that salient factors for the adoption of improved practices include knowledge transfer through social networks, such as extension agents and peer farmers [60,65-67], economic implications (e.g., expected income increment and cost reduction) [68-70], and farmers' attitude toward human and environmental health [58].

To the best of our knowledge, there has been limited quantitative research on the drivers of adoption of the HPRS thus far. The objective of this study was to assess the fac-tors associated with land conversion into the HPRS by analyzing both the likelihood of adoption and the extent of adoption using primary data collected from 253 farming households in four provinces of northern Thailand and the double-hurdle regression analysis. A better understanding of the farm-level determinants of conversion of current farming systems into the HPRS would contribute to improving the policy design for dissemination of alternative farming practices. Following this introductory section, the second section describes the methodology of this study, including the details of study sites, sampling framework, data collection, and statistical analyses; the third and fourth sections present the empirical results and discussions of the findings. Finally, the fifth section delivers conclusion and recommendations.

\section{Materials and Methods}

\subsection{Study Site}

The study was conducted in the northern region of Thailand, which is characterized by the mountainous natural highlands encompassing the upstream of major rivers, such as the Ping, Nan, Yom, and Wang Rivers. The research sites were chosen as per the following criteria: (a) situated in headwater forests, (b) affected by deforestation, forest degradation, and monocropping systems, and (c) the HPRS initiatives focus areas. On this basis, four provinces were purposively selected, namely, Nan, Chiang Mai, Tak, and Lampang (Figure 1). The major crops cultivated in this area are rice (Oryza sativa L.), maize, bean, and other temperate plants. Maize produced for fodder markets has been booming as a cash crop in northern Thailand, accounting for $70 \%$ of the maize production in the country [71]. Rice is produced in both uplands and lowlands, mainly for household consumption.

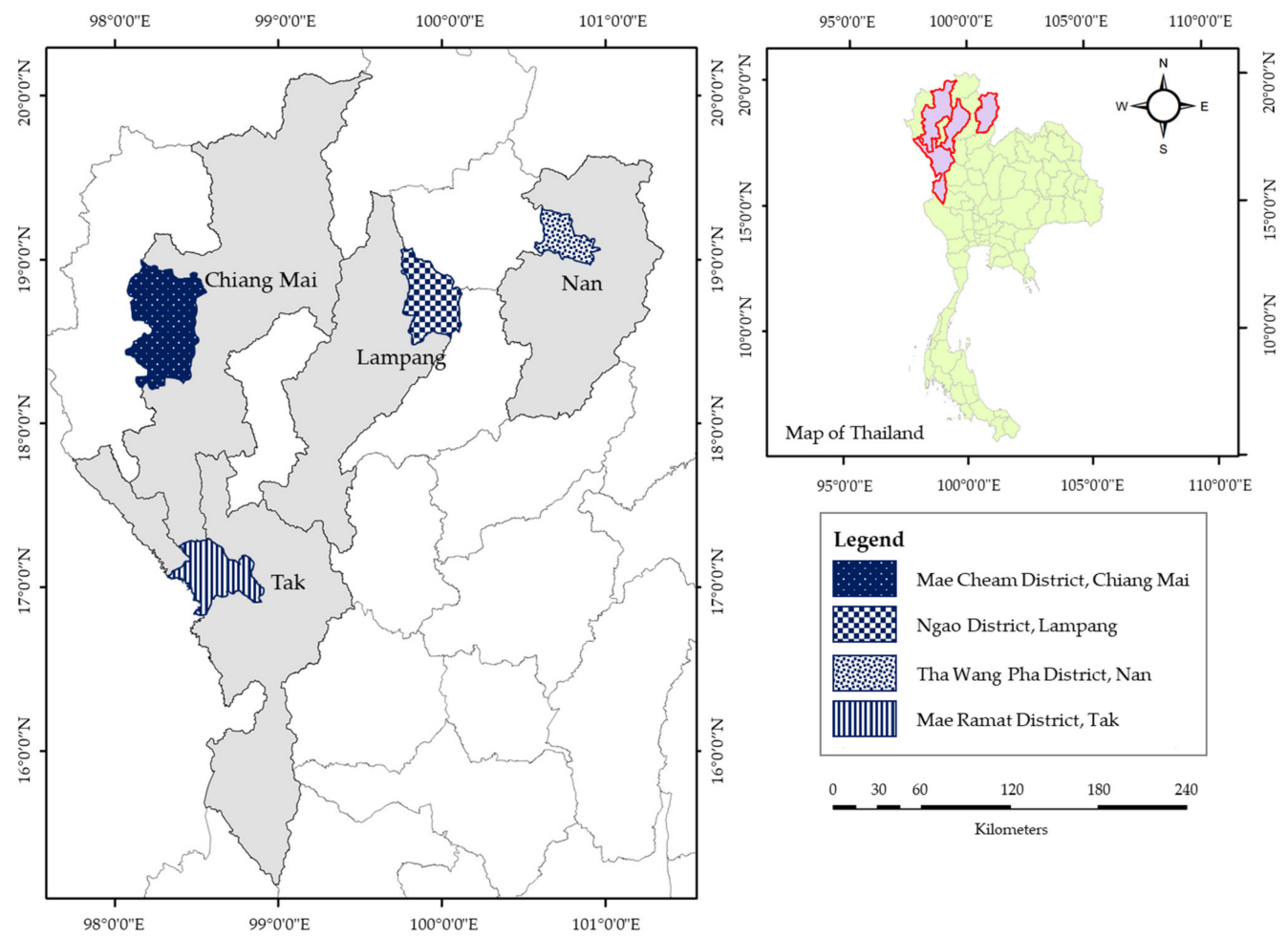

Figure 1. Map of northern Thailand highlighting the four concerned provinces. Source: [72]. 


\subsection{The Hill Pond Rice System}

Thailand has undergone a shift to sustainable agriculture by policies that promote improved land management practices and control deforestation [50]. The promotion of the HPRS is one of the recent initiatives aiming to restore degraded highlands, allowing people to live harmoniously with the ecosystem. The system was initially implemented in Tha Wang Pha District of Nan, Mae Cheam District of Chiang Mai, Mae Ramat District of Tak, and Ngao District of Lampang.

By the HPRS design, the highest altitude area of the farm field is designated to be the hill for forest plantation consisting of "three kinds of forests for four benefits" trees that have different heights and benefits. The lowest altitude area is designated to host a pond consisting of natural water and man-made reservoirs. The pond section is the most important component in rainfed agriculture, subject to water shortage and drought risks. Small check dams are built along small, crooked canals all over the farmland to hold and discharge rainwater into soil for field crops and tree roots. The paddy field section is designated to cultivate organic rice for consumption. With a large high earthen dike, the paddy section is also a water retainer. Furthermore, maintaining water levels in the paddy field can provide habitats for aquatic animals, such as fish, crustaceans, and other small organisms. Besides, the wide earthen dyke has enough space for planting food crops. The capacity of the paddy field dike for home food production provides farmers with a "golden dike" [54].

The five principles of the HPRS are (i) rainwater harvesting and management, (ii) soil amendments and nutrient management, (iii) multi-story tree plantation, (iv) organic rice cultivation, and (v) social network reinforcement. Specific practices under each of the five principles are summarized in Table 1.

\subsection{Data Collection}

Primary data were collected by a household survey through face-to-face interviews using a semi-structured questionnaire from November 2019 to March 2020. Questions were customized based on the Sustainable Livelihood Framework of the Department for International Development (DFID) of the United Kingdom [73]. The structure of the questionnaire is shown in Table 2. The survey collected information on socioeconomic characteristics, livelihood strategies, such as agricultural performance, land resources management, and outcome indicators.

\subsection{Sampling of Farm Households}

All the HPRS implementation sites within the four provinces were included in the survey, which consists of the Mae Cheam district (Chiang Mai), Ngao district (Lampang), Tha Wang Pha district (Nan), and Mae Ramat District (Tak). Farmers from these districts participated in HPRS training workshops delivered by the Institute of Sufficiency Economy, Agri-Nature Foundation, Ministry of Interior, and Ministry of Agriculture and Cooperatives between 2013 and 2018 to sensitize and train farmers on knowledge and practices of efficient water and land resource management and to nurture the mindset of sustainability within the community. Given the limited population that received the training, all the trained farm households were included in the survey.

In this study, the adoption and non-adoption of the HPRS were defined based on land conversion as follows: (i) converters are farmers who converted at least some part of their farmland to implement practices under the HPRS after participating in the HPRS workshop; (ii) non-converters are those who had not allocated any land for HPRS implementation after the workshop participation. In total, there were 129 converters and 124 non-converters at the time of the survey, all of whom were interviewed, rendering the sample size of 253 households. Household heads were the prioritized respondents. When the head was unavailable, however, an alternative representative adult, such as the spouse, was interviewed. Table 3 presents the number of interviewed households by province. 
Table 1. Principles and practices of the Hill Pond Rice System in northern Thailand.

\begin{tabular}{|c|c|c|}
\hline Code & Principle & Description \\
\hline & \multicolumn{2}{|c|}{ Principle 1: Rainwater harvesting and management } \\
\hline $\mathrm{P} 1$ & Land use planning and design & $\begin{array}{l}\text { Analyze farmland terrain to observe surface water drainage patterns, light } \\
\text { and wind directions, and resource availability. Then farmers assess their } \\
\text { family needs. Design the lowest part of land to be water reservoirs and rice } \\
\text { fields and upper parts to be plantation areas and infrastructure. }\end{array}$ \\
\hline P2 & Excavating the free-form water reservoirs & Dig the lowest level of farmland $6 \mathrm{~m}$ deep for free-form water reservoirs. \\
\hline P3 & Excavating crooked canals & $\begin{array}{l}\text { Dig crooked canals on farmland along the contours on a high hill to spread } \\
\text { water. }\end{array}$ \\
\hline $\mathrm{P} 4$ & Building check dams & Build check dams along crooked canals. \\
\hline P5 & Excavating small swamps & Dig small swamps along with check dams. \\
\hline P6 & Building the earth hill & Excavate soil to build an earth hill. \\
\hline \multirow[t]{2}{*}{ P7 } & $\begin{array}{l}\text { Building water containers by using local } \\
\text { materials }\end{array}$ & Build water containers using local materials (e.g., bamboo), soil, and cement. \\
\hline & \multicolumn{2}{|c|}{ Principle 2: Soil amendments and nutrient management } \\
\hline P8 & Zero agrochemicals & No use of synthetic inputs, such as fertilizer, pesticides, growth hormones, etc. \\
\hline P9 & Zero burning & No burning after harvesting and before land preparation for new plantation. \\
\hline P10 & Mulching & $\begin{array}{l}\text { Mulching is applied to bare soil or around existing plants to retain moisture } \\
\text { that favors the activity of worms and other organisms. }\end{array}$ \\
\hline P11 & Composting & Use compost to feed soil with organic matter. \\
\hline P12 & Using green manure & Sow fast-growing plants to cover bare soil. \\
\hline P13 & Using animal manure & Use animal manure from different domestic animals as fertilizers. \\
\hline P14 & Bio-fermented fertilizer use & $\begin{array}{l}\text { Use liquid bio-extract from the fermentation and digestion process of fresh } \\
\text { and succulent organic waste to produce bio-fermented fertilizer. }\end{array}$ \\
\hline \multirow[t]{2}{*}{ P15 } & Bio-extracted pesticide use & $\begin{array}{l}\text { Using liquid bio-extract from the fermentation and digestion process of fresh } \\
\text { and succulent organic wastes to make bio-extracted pesticides. }\end{array}$ \\
\hline & Principle 3: Multistorey tree plantation & \\
\hline P16 & High tree species' plantation & Planting high-level trees, i.e., a large, long-living tree. \\
\hline P17 & Medium height tree species' plantation & Planting mid-story trees, i.e., a perennial crop that provides fruits. \\
\hline P18 & Low height tree species' plantation & Planting low-height species: plants of relatively low height or shrubs. \\
\hline P19 & Ground plant species' plantation & $\begin{array}{l}\text { Planting ground plant species, i.e., a weak-stemmed plant (vegetable, herb), } \\
\text { and a ground cover plant (leguminous species). }\end{array}$ \\
\hline \multirow[t]{2}{*}{ P20 } & Underground plant species' plantation & Planting plants with bulbs, such as ginger, cassava, potato, etc. \\
\hline & Principle 4: Organic rice cultivation & \\
\hline P21 & Cultivating organic rice & Zero synthetic input applied to rice fields. \\
\hline \multirow[t]{2}{*}{$\mathrm{P} 22$} & Having 'the golden dike' & $\begin{array}{l}\text { Building the earthen dike of one-meter width around the rice field where } \\
\text { staple crops or trees can be planted. }\end{array}$ \\
\hline & Principle 5: Social network strengthening & \\
\hline P23 & Sharing labor force & $\begin{array}{l}\text { Sharing labor force as "Aw Mue Aw Haeng", voluntary sharing of workforce } \\
\text { to help peers establish the HPRS. }\end{array}$ \\
\hline P24 & Seed conservation and sharing & Seed conservation and sharing among farmers. \\
\hline P25 & Sharing know-how of the HPRS & $\begin{array}{l}\text { Sharing knowledge of improved land management practices and know-how } \\
\text { among farmers. }\end{array}$ \\
\hline
\end{tabular}


Table 2. Structure of the questionnaire used for the household survey.

\begin{tabular}{|c|c|c|}
\hline Section & Theme & Example Variables \\
\hline \multirow[t]{4}{*}{1} & Socio-demographic profile & $\begin{array}{c}\text { Gender, age, occupation, education, household size, household labor, and marital } \\
\text { status }\end{array}$ \\
\hline & Vulnerability & Natural disaster occurrence cost/price trend \\
\hline & Livelihood asset & Human capital, financial capital, natural capital, physical capital, social capital \\
\hline & Institutional aspect & Access to information, group membership, participation \\
\hline 2 & $\begin{array}{l}\text { Farm management and } \\
\text { HPRS adoption }\end{array}$ & $\begin{array}{l}\text { Cropping patterns, farming activities, soil maintenance, } \\
\text { practices under the HPRS, attitude toward the HPRS }\end{array}$ \\
\hline 3 & Livelihood outcome & $\begin{array}{l}\text { Socioeconomic indicators (yield, income, expenditure), environmental indicators (soil } \\
\text { quality, biodiversity, water availability), social indicators (level of satisfaction) }\end{array}$ \\
\hline 4 & Opinions & Opinions about constraints and comments/recommendations toward development \\
\hline
\end{tabular}

Table 3. Sample size for the household survey by province: full population sampling.

\begin{tabular}{ccc}
\hline Province (District) & Converters & Non-Converters \\
\hline Chiang Mai (Mae Chaem) & 33 & 32 \\
Lampang (Ngao) & 31 & 23 \\
Nan (Tha Wang Pha) & 31 & 35 \\
Tak (Mae Ramat) & 34 & 34 \\
\hline Total & 129 & 124 \\
\hline
\end{tabular}

In addition to the survey, 15 key informants were interviewed to gain in-depth information, which would help interpret quantitative findings from the statistical analysis of the survey data. The key informants were four local coordinators of the HPRS program, two extension agents, two village heads, two subdistrict heads, one district chief, and four informal leaders. Moreover, informal discussions were held with community members with an aim to collect background information, such as cultural and physical environments and build rapport with the community. Field observation was used throughout the survey period to note the cropping patterns, farming systems, land use type, soil quality, water management, and infrastructure.

\subsection{Methods of Analysis}

\subsubsection{Empirical Models}

The decision to adopt any technologies is assumed to consist of two processes: First decide whether or not to adopt; then, decide on the extent of adoption if adopted [40,51,64,74-78]. The first process is measured by a binary variable, which takes the value of one if the technology is adopted and zero otherwise. Accordingly, the probit $[40,64]$ or the logistic $[75,77]$ model is popularly utilized to analyze the factors influencing technology adoption. The second process is measured by a numerical variable, which is censored at zero as all nonadopters allocate no land, by definition. Hence, the tobit regression is widely employed to analyze the factors influencing the extent of adoption [51,75,79-81]. Furthermore, some adoption studies use the double-hurdle model (DHM) $[82,83]$ to incorporate the possibility that the extent of adoption is conditional on the decision to adopt, whereby explanatory variables or their coefficients for the two processes are allowed to differ $[74,76,78,84]$. This study adopted these three models to analyze the adoption of HPRS: The probit for the first stage and both the tobit and the DHM for the second stage to discuss any contrast as well as to examine the robustness of the results.

HPRS adoption, in this study, is mainly defined as and characterized by the conversion of farmland from the maize monocropping system into HPRS. It is worth noting that some of the 25 HPRS practices can be implemented without land conversion and, therefore, had already been practiced by some farmers prior to the HPRS training in 2013. On the other hand, conversion of farmland into the HPRS is peculiar to the HPRS intervention and 
occurred only after the training. Accordingly, the aforementioned two-stage analysis was applied to land conversion to HPRS, where the first stage refers to whether at least part of the farmland was converted, while the second stage refers to the extent of conversion as measured in proportion of farmland converted to HPRS. Hence, in this article, the adopters are hereinafter referred to as the converters, while the non-adopters are referred to as the non-converters. On this basis, the three regression models were constructed.

Equation (1) shows the probit model, which represents the first hurdle of the DHM:

$$
\begin{gathered}
Y_{1 i}^{*}=X_{i} \beta_{1}+\varepsilon_{1 i}, \quad \varepsilon_{1 i} \sim N(0,1) \\
Y_{1 i}=\left\{\begin{array}{c}
1 \text { if } Y_{1 i}^{*}>0 \\
0 \text { otherwise }
\end{array} .\right.
\end{gathered}
$$

where $Y_{1 i}$ is the observed binary variable representing whether farmer $i$ was a converter, $Y_{1 i}^{*}$ is the latent continuous variable representing the likelihood of conversion, $X_{i}$ is a vector of explanatory variables, $\beta_{1}$ is a vector of coefficients to be estimated, and $\varepsilon_{1 i}$ is a random error term that follows the standard normal distribution.

Equation (2) presents the tobit model:

$$
\begin{gathered}
Y_{2 i}^{*}=X_{i} \beta_{2}+\varepsilon_{2 i}, \quad \varepsilon_{2 i} \sim N\left(0, \sigma^{2}\right) \\
Y_{2 i}=\left\{\begin{aligned}
Y_{2 i}^{*} & \text { if } Y_{2 i}^{*}>0 \\
0 & \text { otherwise }
\end{aligned}\right.
\end{gathered}
$$

where $Y_{2 i}$ is farmer $i$ 's observed proportion of farmland converted to HPRS, which is censored at zero, $Y_{2 i}^{*}$ is the latent uncensored version of $Y_{2 i}, \beta_{2}$ is a vector of coefficients to be estimated, and $\varepsilon_{2 i}$ is an error term with mean zero and standard deviation $\sigma$.

Equation (3) describes the second hurdle of the DHM, which is a modification of Equation (2) based on Equation (1):

$$
\begin{gathered}
Y_{2 i}^{*}=X_{i} \widetilde{\beta_{2}}+\rho \cdot I M R_{i}+\widetilde{\varepsilon_{2 i}}, \widetilde{\varepsilon_{2 i}} \sim N\left(0, \widetilde{\sigma}^{2}\right) \\
Y_{2 i}=\left\{\begin{aligned}
Y_{2 i}^{*} & \text { if } Y_{1 i}^{*}>0 \\
0 & \text { otherwise }
\end{aligned}\right.
\end{gathered}
$$

where $I M R_{i}$ is the inverse Mills ratio constructed from the first-tier result as an instrument to control for a selection bias when it exists [3,85], $\widetilde{\beta_{2}}$ is the unbiased estimate of $\beta_{2}$, and $\widetilde{\varepsilon_{2 i}}$ is a random error term with mean zero and standard deviation $\widetilde{\sigma}$.

Additionally, factors associated with the number of implemented HPRS practices were analyzed using the tobit regression, considering the lower censoring at 0 and the upper censoring at 25 in the distribution of the dependent variable.

Equation (4) shows the two-limit tobit model:

$$
\begin{gathered}
Y_{3 i}^{*}=X_{i} \beta_{3}+\varepsilon_{3 i}, \quad \varepsilon_{3 i} \sim N\left(0, \sigma_{3}^{2}\right) \\
Y_{3 i}=\left\{\begin{array}{c}
25 \text { if } Y_{3 i}^{*}>25 \\
Y_{3 i}^{*} \text { if } 0 \leq Y_{3 i}^{*} \leq 25 . \\
0 \text { if } Y_{3 i}^{*}<0
\end{array}\right.
\end{gathered}
$$

where $Y_{3 i}$ is the censored observed number of HPRS practices adopted by farmer $i, Y_{3 i}^{*}$ is the uncensored latent version of $Y_{3 i}, \beta_{3}$ is a vector of coefficients to be estimated, and $\varepsilon_{3 i}$ is an error term with mean zero and standard deviation $\sigma_{3}$.

All the statistical analyses were performed using STATA 17 [86].

\subsubsection{Variables}

Table 4 summarizes the variables included in the three regression models. The choice of explanatory variables was adapted from the Sustainable Livelihood Framework [73] and literature on agricultural technology adoption. The explanatory variables included demographic variables as standard covariates, five types of livelihood capital, namely human capital (e.g., household labor, perception of the HPRS, attitude toward the HPRS), 
natural capital (e.g., land size, number of large trees, number of water sources), physical capital (household asset), financial capital (off-farm income, debt, expenditure, etc.), and social capital (leadership role, community participation, institutional factor), as well as farmers' vulnerability context.

\section{Demographic Characteristics}

Sex (X1): This is a binary variable that takes one if the respondent was male and zero otherwise. In literature, sex of farmers shows mixed effects on agricultural technology adoption. Some research found that female farmers had a better chance of adopting organic farming than male farmers [56,87]. Conversely, male plot managers were more likely to adopt improved farming practices than female managers (e.g., minimum soil disturbance, improved forage technologies) $[75,88,89]$. On the other hand, Nigussie et al. [90] found no significant effect of farmers' sex on adoption of improved land management practices (e.g., agroforestry, soil bund, and stone-faced soil bund) on highlands of Ethiopia. In the present research, the sex variable was included primarily as a covariate to control for any potentially confounding effects.

Age (X2): In literature on agricultural technology adoption, age exhibits both positive and negative influences. Several authors found that age negatively influenced improved farming practices adoption because younger farmers were more progressive and had better access to information that helped facilitate technological innovations [87,91,92]. On the other hand, age is also regarded as a proxy for farming experiences. Azam and Banumathi [93] showed that older farmers were more likely to adopt new technologies. Nonetheless, some literature identified no significant effect of age on adoption of agricultural techniques $[74,75,90,94]$. The present study includes age as a control variable.

Education (X3): The majority of researchers found positive effects of education on the adoption of various technologies (e.g., [87,95-97]), while some authors found no effect on the adoption of improved farming practices (e.g., $[74,75,91])$. In this study, years of schooling is expected to have positive effects on farmland conversion into the HPRS.

\section{Human Capital Variables}

Farming knowledge (X4): Level of farming knowledge was proxied by the number of technical knowledge items related to farming activities. The respondents were asked to identify knowledge items they were familiar with or had undertaken on their farm before. The items included agriculture related activities, such as handicrafts, food processing, postharvest crop management, and livestock raising. Literature suggests that farmers' adoption of a certain technology is partly based on their farming experience and knowledge $[62,97,98]$.

Household size (X5): This variable is expressed as the number of members of the household. Some studies adopted this variable as a proxy for labor availability for agricultural production $[60,91,99]$, whilst it also implies expenditure of the household. This variable is hypothesized to influence the extent of land conversion to the HPRS in one way or the other.

Active member ratio (X6): This variable is defined as the ratio of family laborers to family members for each household. Mozzato et al. [100] stated that both household size and number of laborers in a household were used as indicators of labor availability. Similarly, the number of adult laborers in a household was often used as a factor influencing the adoption of new technologies [101,102]. Furthermore, Ntshangase et al. [97] considered the number of active members (i.e., those who are older than 15 years old and are able to work on a farm) and used the ratio of active members to total household members, which is adopted in the current study.

Complexity of the HPRS (X7): This variable represents the perceived complexity of the HPRS. Farmers were asked if they agreed with each of six statements related to the complexity of HPRS practices to which a binary response $(1=$ Yes, $0=$ No) was recorded. Those statements were: (i) HPRS practices require too much work and are difficult to understand; (ii) the HPRS requires major investment; (iii) the HPRS is not suitable for our 
farmland; (iv) HPRS implementation will face transport problems; (v) there is a shortage of labor exchange in the community; and (vi) economic returns take time to accrue. The proportion of the 'Yes' answers was calculated, where larger values indicated higher levels of complexity perceived by the household $[43,65,75,77]$. This variable is hypothesized to negatively influence land conversion to the HPRS.

Understanding of benefits (X8): This variable represents the expected benefits of HPRS in multiple aspects. Benefits can be in economic (higher income, better risk management), social (well-being, satisfaction), and environmental aspects [91,103-105]. Health consideration has shown prevalence in literature on improved farming practices adoption $[58,92,106,107]$. The current study takes account of farmers' understanding of potential roles of the HPRS in lifting their livelihoods. They were asked if they agree with each of seven statements related to expected benefits of the HPRS to which a binary response ( $1=$ Yes, $0=$ No) was recorded. Those questions were: (i) the HPRS can reduce household expenses; (ii) the HPRS can increase income; (iii) the HPRS can reduce debt; (iv) products from the HPRS can fetch higher prices; (v) the HPRS can produce organic products for consumption; (vi) the HPRS can have enough water from water reservoirs; and (vii) the HPRS can alleviate concern over environmental conditions and human health. The proportion of the 'Yes' answers was calculated, where larger values indicated higher expected benefits of the HPRS.

Additional training (X9): This variable is defined as how many times the household received training in general in the last one year. It included training provided by any organization and the topics included the sufficiency economy theory, agroforestry, organic farming, and integrated farming systems. Access to capacity building is a major factor affecting technology adoption globally $[75,101,108,109]$.

\section{Natural Capital Variables}

Landholding (X10): Literature shows both positive and negative effects of farmland size on technology adoption. Gil et al. [110] and Zeweld et al. [43] found positive effects on the adoption of sustainable practices, whereas Ntshangase et al. [97] and Okon and Idiong [111] found negative effects on the adoption of organic farming and no-till conservation agriculture [97,111]. In the current study, farm size is expected to positively influence land conversion to the HPRS, given the specific requirements as to land conversion and allocation.

Water sources (X11): This variable is defined by the number of water sources accessible by the household, including river, stream, irrigation system, and traditional water supply from the mountains. Accessibility to water sources plays a crucial role in the adoption of improved agricultural practices $[76,112]$. This variable is expected to have positive effects on land conversion to the HPRS.

\section{Physical Capital Variable}

Household asset (X12): This variable is defined as the number of types of asset items held by the household. Respondents were asked to make multiple selection from the list of the asset types including livestock types (e.g., cows, buffalo, pigs, fish), farm equipment, and household items. The number of types of household asset may be linked to the capacity to adopt improved technologies $[62,88,113,114]$. This variable is expected to positively influence land conversion to the HPRS.

\section{Social Capital Variables}

Workforce sharing (X13): This variable is defined as how many times the household had participated in agricultural workforce sharing in the last one year. Collective workforce sharing serves as a platform for social interaction among farmers [62,92,114]. Some improved farming practices, such as organic farming, crop diversification, and soil and water conservation, require intensive care for which collective workforce sharing is a key [115-118]. In the study area, workforce sharing is referred to as "Aw Mue Aw Heang" 
in the local language, which is a form of labor exchange among farmers in and outside the villages, and even in other provinces, especially for labor-intensive farming activities. The frequency of participation in workforce sharing is expected to have positive effects on land conversion to the HPRS.

Leadership (X14): This is a dummy variable that takes one if a household member or a relative is a formal or informal leader of the community, and zero otherwise. In this research, two types of leadership positions were considered. First, formal leadership positions include sub-district heads, village heads, their assistants, who were appointed by the Ministry of the Interior, and the local government officers. Second, informal leadership includes farmers regarded as leaders, such as group representatives, religious leaders in the community, and other positions appointed by the community. Leadership behavior of individuals may imply collective power, ability of innovation, and creativity. Farmers in leadership roles tend to demonstrate a desire to experience new technologies early [68,119]. Leadership is expected to have a positive influence on land conversion to the HPRS.

Land tenure security (X15): Land tenure is expressed as a dummy variable that takes the value of one if households had a secured land title or ownership and zero otherwise. Tenure insecurity is identified in literature as a common obstacle undermining incentives toward investments in land resources [120,121], and tenure security tends to show positive influences on decisions to adopt new technologies and improved agronomic practices $[40,75]$. This variable is expected to have a positive effect on land conversion to the HPRS.

Access to advisory (X16): It is a dummy variable that takes the value of one if the household had regular access to and contact with advisors after the HPRS intervention and zero otherwise. Contact with agricultural extension agents and trainers is among the common catalysts for technology adoption $[60,91,99]$. Hence, this variable is expected to drive land conversion to the HPRS.

\section{Financial Capital Variables}

Off-farm income ratio (X17): This variable is defined as a proportion of off-farm income to total household income. Off-farm income includes any income generated through offfarm activities, such as labor wage, salary, and allowances, as well as remittances. A large share of off-farm income may imply a lower risk of income loss from natural hazards. Literature shows that off-farm income can have significant positive effects on agricultural technology adoption $[62,75,122]$.

Household savings (X18): This variable is a proxy for the household wealth, which can serve as a source of investment into new technologies. It is thus expected to have a positive influence on land conversion to the HPRS.

Additionally, a variable representing negative shocks incurred by the household was included in the analyses.

Negative shocks (X19): This is a binary variable that takes one if the household had experienced any shocks in the last one year and zero otherwise. Shocks included drought, flood, landslide, insect pests or disease outbreak, illness, unemployment, and death of a household member. Experience with negative shocks is regarded as a key determinant of input use, investment, and adoption of improved farming practices [74,123-126]. However, the effects can go both ways. On one hand, extreme climatic hazards (e.g., drought, flood) typically encourage the adoption of improved practices, such as climate smart agriculture $[127,128]$. On the other hand, idiosyncratic shocks, such as illnesses, discourage investment in technology [125]. Therefore, this variable is hypothesized to have either a positive or negative coefficient. 
Table 4. Variables included in the three regression models in assessing the factors associated with the adoption of the Hill Pond Rice System (HPRS) in northern Thailand.

\begin{tabular}{|c|c|c|c|c|c|}
\hline Code & Variable & Description & Type $^{1}$ & $\begin{array}{l}\text { Expected } \\
\text { Sign }^{2}\end{array}$ & Relevant Literature \\
\hline \multicolumn{6}{|c|}{ Dependent Variables } \\
\hline $\mathrm{Y} 1$ & $\begin{array}{c}\text { Farmland conversion to } \\
\text { HPRS }\end{array}$ & $\begin{array}{l}1 \text { if at least some part of } \\
\text { farmland was converted to the } \\
\text { HPRS, } 0 \text { otherwise }\end{array}$ & $\mathrm{D}$ & & \\
\hline $\mathrm{Y} 2$ & $\begin{array}{c}\text { Extent of land conversion } \\
\text { to HPRS }\end{array}$ & $\begin{array}{c}\text { Proportion of farmland } \\
\text { converted to the HPRS }(0-1)\end{array}$ & $\mathrm{N}$ & & \\
\hline $\mathrm{Y} 3$ & HPRS practices adoption & $\begin{array}{l}\text { Number of HPRS practices } \\
\text { implemented }(0-25)\end{array}$ & $\mathrm{N}$ & & \\
\hline \multicolumn{6}{|c|}{ Explanatory Variables } \\
\hline \multicolumn{6}{|c|}{$\begin{array}{l}\text { Demographic } \\
\text { Characteristics }\end{array}$} \\
\hline $\mathrm{X} 1$ & Sex & 1 if male land title, 0 otherwise & $\mathrm{D}$ & \pm & {$[75,88,89]$} \\
\hline $\mathrm{X} 2$ & Age & Number of years & $\mathrm{N}$ & \pm & {$[87,91,92]$} \\
\hline $\mathrm{X} 3$ & Education & Number of years of schooling & $\mathrm{N}$ & + & {$[95-97,114]$} \\
\hline \multicolumn{6}{|c|}{ Human Capital } \\
\hline $\mathrm{X} 4$ & Farming knowledge & $\begin{array}{l}\text { Number of farming knowledge } \\
\text { items familiar or farming } \\
\text { practices ever adopted by the } \\
\text { household }\end{array}$ & $\mathrm{N}$ & + & {$[62,97,98]$} \\
\hline X5 & Household size & Number of family members & $\mathrm{N}$ & \pm & {$[60,99]$} \\
\hline $\mathrm{X} 6$ & Active member ratio & $\begin{array}{l}\text { Number of laborers in the } \\
\text { household/household size }\end{array}$ & $\mathrm{N}$ & + & {$[97,101,102]$} \\
\hline $\mathrm{X} 7$ & Complexity of the HPRS & $\begin{array}{l}\text { Perceived level of complexity of } \\
\text { HPRS practices (Proportion 0-1) }\end{array}$ & $\mathrm{N}$ & - & {$[43,65,75,77]$} \\
\hline $\mathrm{X} 8$ & Understanding of benefits & $\begin{array}{l}\text { Understanding of benefits of the } \\
\text { HPRS (Proportion 0-1) }\end{array}$ & $\mathrm{N}$ & + & {$[91,103-105]$} \\
\hline X9 & Additional training & $\begin{array}{l}\text { Number of training sessions } \\
\text { received in the last one year } \\
\text { (times/year) }\end{array}$ & $\mathrm{N}$ & + & {$[75,101,108]$} \\
\hline \multicolumn{6}{|c|}{ Natural Capital } \\
\hline $\mathrm{X} 10$ & Landholding & Landholding size (ha) & $\mathrm{N}$ & + & {$[43,97,110,111]$} \\
\hline $\mathrm{X} 11$ & Water sources & $\begin{array}{l}\text { Number of water sources } \\
\text { accessible }\end{array}$ & $\mathrm{N}$ & + & {$[76,112]$} \\
\hline \multicolumn{6}{|c|}{ Physical Capital } \\
\hline $\mathrm{X} 12$ & Household asset & $\begin{array}{c}\text { Number of household asset } \\
\text { items }\end{array}$ & $\mathrm{N}$ & + & {$[62,88,113,114]$} \\
\hline \multicolumn{6}{|c|}{ Social Capital } \\
\hline $\mathrm{X} 13$ & Workforce sharing & $\begin{array}{l}\text { Number of times that the } \\
\text { household participated in a } \\
\text { workforce sharing event in the } \\
\text { community (times/year) }\end{array}$ & $\mathrm{N}$ & + & {$[62,92,114]$} \\
\hline $\mathrm{X} 14$ & Leadership & $\begin{array}{c}1 \text { if a household member or a } \\
\text { relative is in a leadership } \\
\text { position, } 0 \text { otherwise }\end{array}$ & $\mathrm{D}$ & + & {$[68,119]$} \\
\hline $\mathrm{X} 15$ & Land tenure security & $\begin{array}{l}1 \text { if the household holds secured } \\
\text { land title, } 0 \text { otherwise }\end{array}$ & $\mathrm{D}$ & + & {$[40,75,120,121]$} \\
\hline
\end{tabular}


Table 4. Cont.

\begin{tabular}{|c|c|c|c|c|c|}
\hline Code & Variable & Description & Type $^{1}$ & $\begin{array}{l}\text { Expected } \\
\text { Sign }^{2}\end{array}$ & Relevant Literature \\
\hline $\mathrm{X} 16$ & Access to advisory & $\begin{array}{l}1 \text { if the household had access to } \\
\text { extension advice after the HPRS } \\
\text { training, } 0 \text { otherwise }\end{array}$ & $\mathrm{D}$ & + & {$[60,91,99]$} \\
\hline \multicolumn{6}{|c|}{ Financial Capital } \\
\hline $\mathrm{X} 17$ & Off-farm income ratio & $\begin{array}{c}\text { Share of off-farm income in } \\
\text { household income (Percentage) }\end{array}$ & $\mathrm{N}$ & + & {$[57,62,70,75,117,122]$} \\
\hline $\mathrm{X} 18$ & Household savings & $\begin{array}{l}\text { Amount of household saving } \\
\text { (THB) }\end{array}$ & $\mathrm{N}$ & + & The authors \\
\hline \multicolumn{6}{|c|}{ Vulnerability Context } \\
\hline X19 & Negative shocks & $\begin{array}{c}1 \text { if the household experienced } \\
\text { any shock in the last one year, } 0 \\
\text { otherwise }\end{array}$ & $\mathrm{D}$ & \pm & {$[74,123-128]$} \\
\hline
\end{tabular}

${ }^{1} \mathrm{~N}$ : Numerical variable, D: Dummy variable; ${ }^{2}+$ and - indicate a positive and negative sign of the estimated coefficient on each variable.

\section{Results}

\subsection{Socioeconomic Characteristics of the Farmers}

Tables 5 and 6 descriptively summarize the binary variables and numerical variables, respectively, representing the characteristics of land converters and non-converters, along with the $p$-values obtained from the inferential tests. The tables display the 19 explanatory variables included in the regression models and three other variables, namely household laborers, total household income, and household expenditure. Those three latter variables were excluded from the regression models because of the multicollinearity with one or more of the other independent variables based on the variance inflation factor.

Table 5. Descriptive statistics for respondents' characteristics: Binary variables.

\begin{tabular}{cccccccc}
\hline \multirow{2}{*}{ Code } & \multirow{2}{*}{ Characteristics } & \multirow{2}{*}{ Units } & \multicolumn{2}{c}{ Converters $(\boldsymbol{n}=\mathbf{1 2 9})$} & \multicolumn{2}{c}{ Non-Converters $(\boldsymbol{n}=\mathbf{1 2 4})$} & \multirow{2}{*}{$\boldsymbol{p}$-Value } \\
\cline { 3 - 6 } & & & Frequency & $\mathbf{\%}$ & Frequency & \% & \\
\hline X1 & Sex & 1 if male, 0 if female & 80 & 62.0 & 61 & 49.2 & $0.040^{* *}$ \\
X14 & Leadership & 1 if yes, 0 otherwise & 44 & 34.0 & 12 & 9.7 & $0.000^{* * *}$ \\
X15 & Land tenure security & 1 if secured, 0 otherwise & 27 & 20.2 & 55 & 30.6 & $0.000^{* * *}$ \\
X16 & Access to advisory & 1 if yes, 0 otherwise & 51 & 39.5 & 15 & 12.0 & $0.000^{* * *}$ \\
X19 & Negative shocks & 1 if yes, 0 otherwise & 20 & 15.5 & 36 & 29.0 & $0.001^{* * *}$ \\
\hline
\end{tabular}

*** and ${ }^{* *}$ indicate $p<0.01$ and $<0.05$, respectively. The $p$-values are for the $\chi^{2}$ test.

Table 6. Descriptive statistics for respondents' characteristics: Numerical variables.

\begin{tabular}{|c|c|c|c|c|c|c|c|}
\hline \multirow{2}{*}{ Code } & \multirow{2}{*}{ Characteristics } & \multirow{2}{*}{ Units } & \multicolumn{2}{|c|}{ Converters $(n=129)$} & \multicolumn{2}{|c|}{ Non-Converters $(n=124)$} & \multirow{2}{*}{$p$-Value } \\
\hline & & & Range & Mean (SD) & Range & Mean (SD) & \\
\hline $\mathrm{X} 2$ & Age & Years & $24-81$ & $48.6(10.6)$ & $40-72$ & $53.4(5.6)$ & $0.000 * * *$ \\
\hline $\mathrm{X} 3$ & Education & Years & $0-16$ & $9.0(4.0)$ & $0-16$ & $6.8(3.4)$ & $0.000 * * *$ \\
\hline $\mathrm{X} 4$ & Farming knowledge & Number of items & $0-4$ & $3.0(1.3)$ & $0-4$ & $1.6(1.2)$ & $0.000 * * *$ \\
\hline X5 & Household size & Head count & $2-12$ & $4.3(1.6)$ & $2-8$ & $4.4(1.2)$ & 0.534 \\
\hline Ex & Household laborer & Head count & $1-6$ & $2.6(1.1)$ & $1-5$ & $2.5(1.0)$ & 0.840 \\
\hline X6 & Active member ratio & Ratio 0-1 & $0.25-1.00$ & $0.62(0.21)$ & $0.20-1.00$ & $0.58(0.19)$ & 0.193 \\
\hline Ex & Total household income & THB 1000 & 27.6-1200.0 & $191.3(173.0)$ & $26.0-510.0$ & $168.7(102.2)$ & 0.208 \\
\hline Ex & Household expenditure & THB 1000 & $108.0-535.9$ & $81.0(87.8)$ & $27.8-494.0$ & $110.1(80.2)$ & $0.006^{* * *}$ \\
\hline $\mathrm{X} 7$ & Complexity of the HPRS & Ratio 0-1 & $0.20-1.00$ & $0.32(0.23)$ & $0.20-1.00$ & $0.55(0.29)$ & $0.000 * * *$ \\
\hline $\mathrm{X} 8$ & Understanding of benefits & Ratio 0-1 & $0.35-0.83$ & $0.58(0.12)$ & $0.12-0.77$ & $0.43(0.14)$ & $0.000 * * *$ \\
\hline X9 & Additional training & Times/year & $0-5$ & $3.5(1.4)$ & $0-5$ & $2.1(1.3)$ & $0.000 * * *$ \\
\hline
\end{tabular}


Table 6. Cont.

\begin{tabular}{|c|c|c|c|c|c|c|c|}
\hline \multirow{2}{*}{ Code } & \multirow{2}{*}{ Characteristics } & \multirow{2}{*}{ Units } & \multicolumn{2}{|c|}{ Converters $(n=129)$} & \multicolumn{2}{|c|}{ Non-Converters ( $n=124)$} & \multirow{2}{*}{$p$-Value } \\
\hline & & & Range & Mean (SD) & Range & Mean (SD) & \\
\hline $\mathrm{X} 10$ & Landholding & ha & $1.28-12.80$ & $5.06(2.61)$ & $1.60-11.20$ & $4.91(1.92)$ & 0.617 \\
\hline $\mathrm{X} 11$ & Water sources & Number of sources & $1-3$ & $1.6(0.6)$ & $1-2$ & $1.3(0.4)$ & $0.000^{* * *}$ \\
\hline $\mathrm{X} 12$ & Household asset & Number of items & $2-14$ & $7.7(2.3)$ & $2-14$ & $7.7(2.1)$ & 0.895 \\
\hline $\mathrm{X} 13$ & Workforce sharing & Times/year & $1-7$ & $3.0(1.4)$ & $1-3$ & $1.8(0.8)$ & $0.000^{* * *}$ \\
\hline $\mathrm{X} 17$ & Off-farm income ratio & Percentage & $1.0-92.0$ & $42.1(21.5)$ & $1.0-85.0$ & $32.1(20.9)$ & $0.002 * * *$ \\
\hline
\end{tabular}

*** indicates $p<0.01$. The exchange rate was USD $1=$ THB 31.4 as of the data collection period in January-April 2020. Ex indicates variables excluded from the regression models due to the high multicollinearity. The $p$-values are for the two-sample $t$ test.

The male ratio was higher among the converters than among the non-converters $(p=0.040)$. The converters were 4.8 years younger than the non-converters on average $(p=0.000)$, though the eldest farmer (81 years) was a converter. The average household size (number of members per household) was not significantly different $(p=0.534)$ between the converters (4.3) and non-converters (4.4), while it was considerably higher than the national average (3.1) [129]. The average number of household laborers was not significantly different ( $p=0.840$ ) between the converters ( 2.6 heads) and the non-converters (2.5). Average frequency of participation in workforce exchange was higher for the converters (3.0) than for the non-converters (1.8).

The average landholding was not significantly different $(p=0.617)$ between the converters (5.1 ha per household) and the non-converters (4.9), while it was larger than the national average of 4.0 ha [130]. However, there was a significant difference $(p=0.000)$ in proportion of land certificate holders between the converters $(20 \%)$ and the non-converters $(31 \%)$. The average household income was not significantly different either $(p=0.208$; THB 191,000 vs. 169,000 /year), while it was much lower than the national average for farmers (THB 312,000/year) [129]. The average proportion of off-farm income was significantly higher $(p=0.002)$ for the converters $(0.42)$ than for the non-converters $(0.32)$. As per the average annual household expenditure, the converters spent less (THB 84,000) than the non-converters (THB 114,000) $(p=0.006)$, which was much lower than the national average of THB 248,000 [129]. Another indicator of wealth is asset holding. The number of household asset types was 7.7 types on average, with no significant difference between the two groups $(p=0.875)$. The converters had greater precautionary savings on average (THB 43,000) than the non-converters (THB 13,000) $(p=0.003)$.

\subsection{Extent of HPRS Adoption}

Figure 2 presents the proportion of households implementing each of the 25 specific HPRS practices (recall Table 1) per group. The most popularly implemented practices were zero burning (P9), planting edible plant species (e.g., vegetables and herbs) (P19), low height tree species (P18), underground species (e.g., root and tuber crops) (P20), medium height tree species (e.g., fruit trees) (P17), and tall tree species (P16). Seed sharing (P24), animal manure (P13), rice cultivation for consumption (P21), composting (P11), and biofermented fertilizer (P14) were also common in the study areas with at least a 50\% adoption rate. Green manure (P12), bio-extracted pesticide (P15), and zero-synthetic chemicals were implemented at the $40 \%$ adoption rate. 


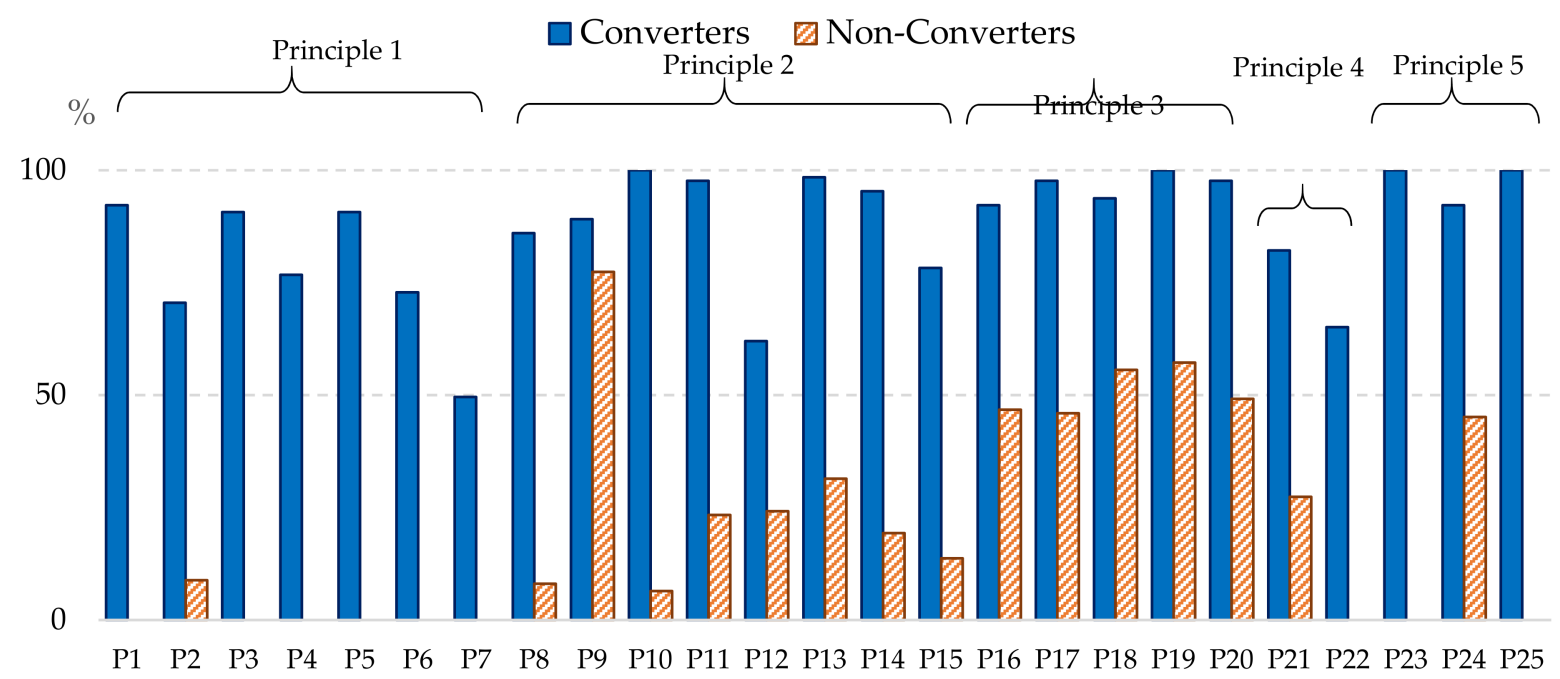

Figure 2. Percentage of households implementing each of the 25 specific HPRS practices in northern Thailand.

On the other hand, the following practices were implemented only by the converters: Land use planning and design (P1), excavating water reservoirs (P2), excavating crooked canals (P3), building check dams (P4), excavating swamps (P5), use of soil from excavation to build an earth hill for planting multi-story tree species (P6), building water containers with local materials (e.g., bamboo, a mix of earth and cement) (P7), workforce sharing (P23), knowledge sharing for improved farming practices (P25), and planting food plant species on 'the golden dike' (P22). Of all the HPRS practices, P7 was the least implemented in the study areas.

Figure 3 illustrates the distribution extent of land converted to the HPRS as a result of the HPRS training. No farmer converted more than $80 \%$ of their farmland, and the majority of them converted less than a half of their farmland. The average proportion of land converted to the HPRS was 0.28 among the converters and 0.14 for the whole sample.

$\%$ of households

60

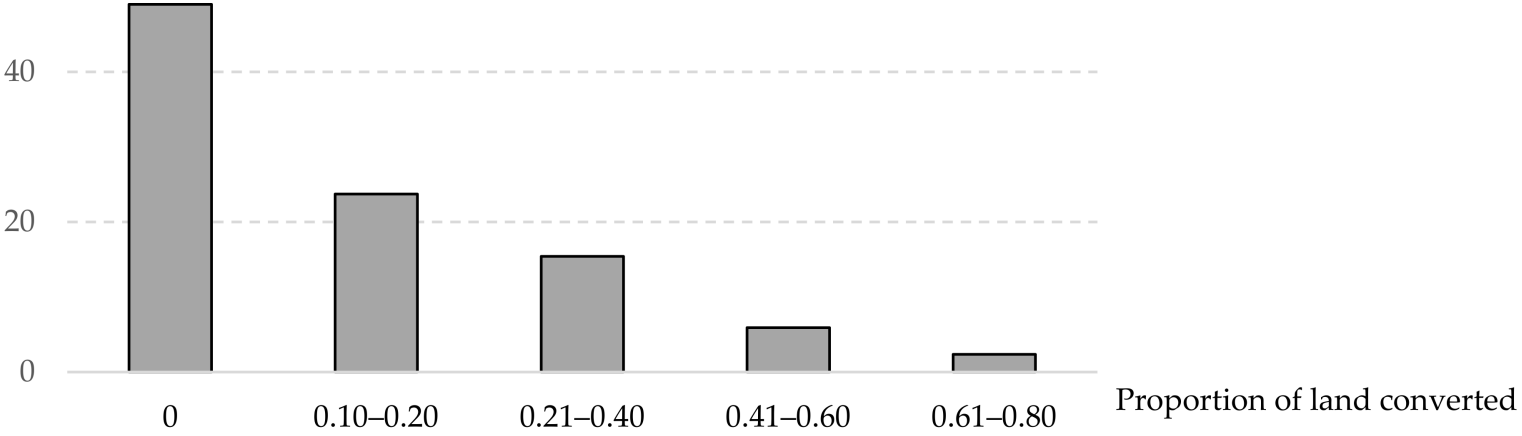

Figure 3. Percentage of households that converted farmland to the HPRS to varying extents in northern Thailand.

Figure 4 illustrates the distribution of the numbers of HPRS practices implemented out of the designated 25 . The land converters implemented 15-25 practices, whilst most of the non-converters implemented in the range of 1-14. Thirteen percent of the converters implemented all 25 HPRS practices, 54\% implemented $21-24$ practices, and the rest (32\%) 
implemented 15-20. Among the non-converters, 73\% implemented 1-7 practices, while the remaining $27 \%$ implemented $8-23$. The average number of implemented practices was 21.6 among the converters, 7.1 among the non-converters, and 14.5 for the whole sample.

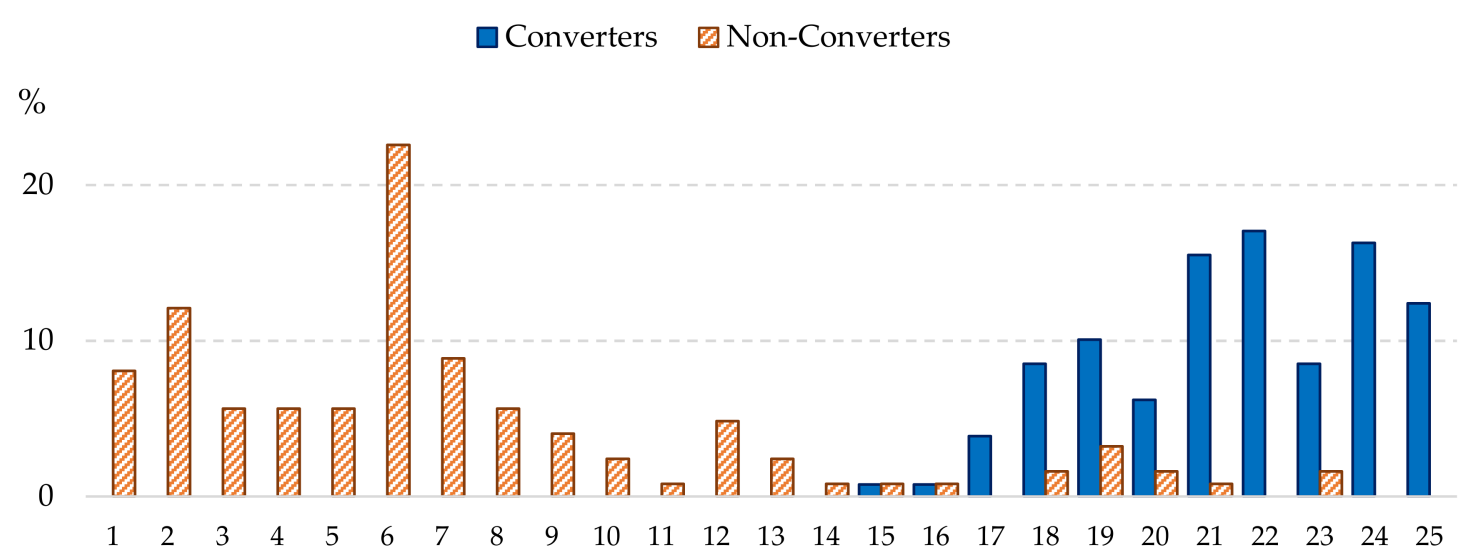

Figure 4. Percentage of households implementing different numbers of designated HPRS practices in northern Thailand.

\subsection{Determinants of HPRS Adoption}

Table 7 presents the first-hurdle probit estimates of factors associated with whether the farmers were converters or non-converters. Out of the 19 independent variables, 9 showed statistically significant effects at least at the $10 \%$ significance level, of which 6 variables (i.e., farming knowledge, understanding of benefits, additional training, water sources, workforce sharing, access to advisory) had positive effects, whereas the three others (i.e., complexity of the HPRS, land tenure security, and negative shocks) had negative effects on the likelihood of land conversion to the HPRS.

Table 7. The first-hurdle probit estimates of the determinants of the likelihood of farmland conversion to the HPRS.

\begin{tabular}{|c|c|c|c|c|c|c|}
\hline \multirow{2}{*}{ Code } & \multirow{2}{*}{ Variable } & \multirow{2}{*}{ Unit } & \multicolumn{4}{|c|}{ 1st Hurdle (Probit Model) } \\
\hline & & & Coeff. & $p$-Value & Marg. Eff. & $p$-Value \\
\hline Y1 & Land conversion to the HPRS & 1 or 0 & & & & \\
\hline $\mathrm{X} 1$ & Sex & 1 if male, 0 if female & 0.225 & 0.518 & 0.023 & 0.518 \\
\hline $\mathrm{X} 2$ & Age & Years & -0.016 & 0.514 & -0.002 & 0.515 \\
\hline X3 & Education & Years & -0.006 & 0.918 & -0.001 & 0.918 \\
\hline $\mathrm{X} 4$ & Farming knowledge & Number of knowledge items & $0.688^{* * *}$ & 0.000 & $0.071^{* * *}$ & 0.000 \\
\hline$\times 5$ & Household size & Head count & -0.154 & 0.228 & -0.016 & 0.224 \\
\hline X6 & Active member ratio & 0 to 1 & -0.101 & 0.902 & -0.010 & 0.902 \\
\hline$X 7$ & Complexity of the HPRS & 0 to 1 & $-2.246^{* * *}$ & 0.001 & $-0.231^{* * *}$ & 0.000 \\
\hline X8 & Understanding of benefits & 0 to 1 & $9.288^{* * *}$ & 0.000 & $0.956^{* * *}$ & 0.000 \\
\hline X9 & Additional training & Times/year & $0.339 * *$ & 0.045 & $0.035^{* *}$ & 0.036 \\
\hline $\mathrm{X} 10$ & Landholding & ha & 0.033 & 0.685 & 0.003 & 0.685 \\
\hline $\mathrm{X} 11$ & Water sources & Number of sources & $2.086^{* * *}$ & 0.000 & $0.215^{* * *}$ & 0.000 \\
\hline $\mathrm{X} 12$ & Household asset & Number of items & 0.092 & 0.358 & 0.009 & 0.355 \\
\hline $\mathrm{X} 13$ & Workforce sharing & Times/year & $0.441 * * *$ & 0.008 & $0.045^{* * *}$ & 0.004 \\
\hline X14 & Leadership & 1 or 0 & -0.611 & 0.219 & -0.063 & 0.212 \\
\hline $\mathrm{X} 15$ & Land tenure security & 1 or 0 & $-1.349^{* * *}$ & 0.002 & $-0.139^{* * *}$ & 0.000 \\
\hline $\mathrm{X} 16$ & Access to advisory & 1 or 0 & $0.711 *$ & 0.085 & $0.077^{*}$ & 0.071 \\
\hline $\mathrm{X} 17$ & Off-farm income ratio & 0 to 1 & 0.878 & 0.293 & 0.090 & 0.291 \\
\hline $\mathrm{X} 18$ & Household savings & THB $1,000,000$ & 4.938 & 0.128 & 0.508 & 0.120 \\
\hline \multirow[t]{2}{*}{ X19 } & Negative shocks & 1 or 0 & $-1.698^{* * *}$ & 0.001 & $-0.175^{* * *}$ & 0.000 \\
\hline & Constant & & $-9.540 * * *$ & 0.000 & & \\
\hline
\end{tabular}


Table 7. Cont.

\begin{tabular}{|c|c|c|c|c|c|c|}
\hline \multirow{2}{*}{ Code } & \multirow{2}{*}{ Variable } & \multirow{2}{*}{ Unit } & \multicolumn{4}{|c|}{ 1st Hurdle (Probit Model) } \\
\hline & & & Coeff. & $p$-Value & Marg. Eff. & $p$-Value \\
\hline & Num. of obs. & & 253 & & & \\
\hline & LR $\chi 2$ (19) & & 256.510 & & & \\
\hline & $p$-value & & 0.000 & & & \\
\hline & Pseudo $R 2$ & & 0.732 & & & \\
\hline & Log likelihood & & -47.063 & & & \\
\hline
\end{tabular}

$* * * * *$, and ${ }^{*}$ stand for $p<0.01,<0.05$, and $<0.10$, respectively.

Specifically, having one additional knowledge item raised the probability of land conversion by $7 \%$ on average, holding all the other variables constant. When perceived levels of complexity of the HPRS increased by 0.1 unit, the probability of land conversion decreased by $2 \%$. When understanding of benefits from the HPRS increased by 0.1 unit, the probability of land conversion increased by $10 \%$. Receiving one additional training session per year increased the probability of land conversion by $4 \%$. Having one additional water source increased the probability of land conversion by $22 \%$. Increasing the frequency of participation in workforce sharing by one more time a year led to increasing the probability of land conversion by $5 \%$. Having land tenure security led to reducing the probability of land conversion by $14 \%$ compared with having no land tenure security. Having access to advisory resulted in raising the probability of land conversion by $8 \%$ compared with having no such access. Recent experience with negative shocks decreased the probability of land conversion by $18 \%$.

The 11 other variables did not significantly influence farmers' likelihood of converting farmland into the HPRS, namely gender, age, education level, household size, active member ratio, landholding, household asset holding, leadership potential, off-farm income ratio, and household savings.

Table 8 presents the estimates of the factors associated with the extent of land conversion into the HPRS based on the second hurdle of the DHM and the tobit model. As per the DHM results, five variables showed statistically significant effects, of which four (i.e., farming knowledge, water sources, workforce sharing, and off-farm income ratio) were positive, whereas complexity of the HPRS had negative effects. As per the tobit results, nine variables showed significant effects, of which seven (i.e., farming knowledge, understanding of benefits, water sources, workforce sharing, off-farm income, and household savings) were positive, whilst three variables (i.e., complexity of the HPRS, land tenure security, and negative shocks) were negative.

Table 8. The estimated determinants of the extent of farmland conversion to the HPRS: The second hurdle of the double-hurdle model (DHM) and the tobit model.

\begin{tabular}{|c|c|c|c|c|c|c|}
\hline \multirow[t]{2}{*}{ Code } & \multirow[t]{2}{*}{ Variable } & \multirow[t]{2}{*}{ Unit } & \multicolumn{2}{|c|}{$\begin{array}{c}\text { 2nd Hurdle of the } \\
\text { DHM }\end{array}$} & \multicolumn{2}{|c|}{ Tobit } \\
\hline & & & Coeff. & $p$-Value & Coeff. & $p$-Value \\
\hline $\mathrm{Y} 2$ & $\begin{array}{l}\text { Proportion of land area } \\
\text { converted to the HPRS }\end{array}$ & Ratio 0-1 & & & & \\
\hline $\mathrm{X} 1$ & Sex & 1 if male, 0 if female & -0.042 & 0.334 & -0.034 & 0.280 \\
\hline $\mathrm{X} 2$ & Age & Years & -0.002 & 0.342 & -0.001 & 0.709 \\
\hline $\mathrm{X} 3$ & Education & Years & -0.002 & 0.764 & 0.004 & 0.427 \\
\hline $\mathrm{X} 4$ & Farming knowledge & Number of knowledge items & $0.051^{* * *}$ & 0.006 & $0.065^{* * *}$ & 0.000 \\
\hline $\mathrm{X} 5$ & Household size & Head count & -0.041 & 0.209 & -0.024 & 0.219 \\
\hline $\mathrm{X} 6$ & Active member ratio & 0 to 1 & -0.107 & 0.263 & 0.044 & 0.529 \\
\hline
\end{tabular}


Table 8. Cont.

\begin{tabular}{|c|c|c|c|c|c|c|}
\hline \multirow[t]{2}{*}{ Code } & \multirow[t]{2}{*}{ Variable } & \multirow[t]{2}{*}{ Unit } & \multicolumn{2}{|c|}{$\begin{array}{l}\text { 2nd Hurdle of the } \\
\text { DHM }\end{array}$} & \multicolumn{2}{|c|}{ Tobit } \\
\hline & & & Coeff. & $p$-Value & Coeff. & $p$-Value \\
\hline X7 & Complexity of the HPRS & 0 to 1 & $-0.202 * *$ & 0.024 & $-0.229 * * *$ & 0.000 \\
\hline X8 & Understanding of benefits & 0 to 1 & 0.128 & 0.429 & $0.610 * * *$ & 0.000 \\
\hline X9 & Additional training & Times/year & 0.003 & 0.880 & 0.016 & 0.236 \\
\hline X10 & Landholding & ha & -0.007 & 0.423 & -0.003 & 0.587 \\
\hline X11 & Water sources & Number of sources & $0.064 *$ & 0.065 & $0.136^{* * *}$ & 0.000 \\
\hline X12 & Household asset & Number of items & -0.015 & 0.152 & -0.006 & 0.414 \\
\hline X13 & Workforce sharing & Times/year & $0.046^{* * *}$ & 0.001 & $0.052 * * *$ & 0.000 \\
\hline X14 & Leadership & 1 or 0 & 0.010 & 0.846 & 0.016 & 0.681 \\
\hline X15 & Land tenure security & 1 or 0 & 0.035 & 0.510 & $-0.106^{* * *}$ & 0.004 \\
\hline X16 & Access to advisory & 1 or 0 & 0.011 & 0.811 & 0.019 & 0.592 \\
\hline X17 & Off-farm income ratio & 0 to 1 & $0.251^{* *}$ & 0.011 & $0.165^{* *}$ & 0.019 \\
\hline X18 & Household savings & THB $1,000,000$ & 0.195 & 0.295 & $0.374^{* *}$ & 0.020 \\
\hline \multirow[t]{8}{*}{ X19 } & Negative shocks & 1 or 0 & -0.022 & 0.809 & $-0.151^{* * *}$ & 0.003 \\
\hline & Constant & & 0.242 & 0.366 & $-0.582 * * *$ & 0.002 \\
\hline & Num. of obs. & & & 253 & & 253 \\
\hline & $\begin{array}{c}\text { Num. of left-censored obs. at } \\
\text { zero. }\end{array}$ & & & na & & 124 \\
\hline & Wald $\chi 2$ (19) & & & 53.12 & $\begin{array}{l}\mathrm{LR} \chi 2 \\
(19):\end{array}$ & 256.86 \\
\hline & $p$-value & & & 0.000 & & 0.000 \\
\hline & Pseudo $R 2$ & & & na & & 1.053 \\
\hline & Log likelihood & & & 33.536 & & 6.743 \\
\hline
\end{tabular}

$* * * * *$, and ${ }^{*}$ stand for $p<0.01,<0.05$, and $<0.10$, respectively.

Taking the DHM results, the quantitative interpretation of each significant variable is as follows. Having one additional knowledge item increased the proportion of converted land by five percentage points on average, holding the covariates constant. Increasing the perceived levels of complexity of the HPRS by 0.1 unit decreased the proportion of land conversion by 2 percentage points. Having one additional water source increased the proportion of land conversion by six percentage points. When the frequency of participation in workforce sharing increased by one more time a year, the proportion of land conversion increased by five percentage points. Increasing the proportion of off-farm income by 0.1 increased the proportion of land conversion by 2.5 percentage points.

Table 9 presents the estimates of the factors associated with the number of HPRS practices implemented. Nine variables showed significant effects, of which seven (i.e., education level, farming knowledge, understanding of benefits, additional training, water sources, workforce sharing, off-farm income ratio) were positive, whereas two (i.e., complexity of the HPRS, land tenure security) were negative.

Specifically, one additional year of education increased the number of adopted HPRS practices by 0.3 on average, keeping the covariates unchanged. Having one additional knowledge item increased the number of adopted practices by 1.2 on average. When perceived levels of complexity of the HPRS increased by 0.1 unit, the number of adopted practices decreased by 0.4 . For an increase in levels of understanding of benefits by 0.1 unit, the same number increased by 1.6. Receiving one additional training session per year increased the number by 0.6 . Having one additional water source increased the number by 3.0. Increasing the frequency of participation in workforce sharing by one more time a year increased the number by 1.3. Having land tenure security led to reducing the number by 4.1 compared with having no land tenure security. When off-farm income ratio increased by 0.1 , the number increased by 0.3 . 
Table 9. The estimated determinants of the number of HPRS practices adopted: the tobit regression.

\begin{tabular}{|c|c|c|c|c|}
\hline Code & Variable & Unit & Coeff. & $p$-Value \\
\hline Y3 & $\begin{array}{c}\text { Number of HPRS practices } \\
\text { implemented }\end{array}$ & Number of practices & & \\
\hline $\mathrm{X} 1$ & Sex & 1 if male, 0 if female & -0.637 & 0.400 \\
\hline $\mathrm{X} 2$ & Age & Years & 0.065 & 0.192 \\
\hline X3 & Education & Years & $0.317 * * *$ & 0.009 \\
\hline X4 & Farming knowledge & Number of knowledge items & $1.175^{* * *}$ & 0.000 \\
\hline$X 5$ & Household size & Head count & -0.329 & 0.221 \\
\hline$X 6$ & Active member ratio & 0 to 1 & 1.568 & 0.380 \\
\hline X7 & Complexity of the HPRS & 0 to 1 & $-4.228^{* * *}$ & 0.001 \\
\hline X8 & Understanding of benefits & 0 to 1 & $16.159 * * *$ & 0.000 \\
\hline X9 & Additional training & Times/year & $0.597 *$ & 0.083 \\
\hline X10 & Landholding & ha & 0.060 & 0.718 \\
\hline X11 & Water sources & Number of sources & $3.001^{* * *}$ & 0.000 \\
\hline $\mathrm{X} 12$ & Household asset & Number of items & -0.132 & 0.489 \\
\hline X13 & Workforce sharing & Times/year & $1.272^{* * *}$ & 0.000 \\
\hline X14 & Leadership & 1 or 0 & 1.438 & 0.197 \\
\hline X15 & Land tenure security & 1 or 0 & $-4.127^{* * *}$ & 0.000 \\
\hline X16 & Access to advisory & 1 or 0 & 0.655 & 0.506 \\
\hline X17 & Off-farm income ratio & 0 to 1 & $3.105 *$ & 0.080 \\
\hline X18 & Household savings & THB $1,000,000$ & 3.489 & 0.448 \\
\hline \multirow[t]{8}{*}{ X19 } & Negative shocks & 1 or 0 & -0.460 & 0.624 \\
\hline & Constant & & $-7.887 *$ & 0.066 \\
\hline & Num. of obs. & & 253 & \\
\hline & $\begin{array}{l}\text { Num. of left-censored obs. at } \\
25 .\end{array}$ & & 16 & \\
\hline & $\operatorname{LR} \chi 2(19)$ & & 257.46 & \\
\hline & $p$-value & & 0.000 & \\
\hline & Pseudo R2 & & 0.148 & \\
\hline & Log likelihood & & -738.742 & \\
\hline
\end{tabular}

*** and ${ }^{*}$ stand for $p<0.01$ and $<0.10$, respectively.

\section{Discussions}

The proportion of farmland converted to the HPRS was 0.28 on average and 0.80 at the maximum. Some farmers set aside the majority of their land for cash crops outside the HPRS. As for the number of adopted HPRS practices, the land converters adopted 21.6 practices on average, while the non-converters adopted 7.1. As shown in Figure 2, land conversion was highly linked to the first principle of the HPRS, i.e., water harvesting and management. Most of the non-converters did not adopt the practices under Principle 1 (P1-P7), except excavating a water pond (P2). Due to the control over residue burning [131], most of the farmers in the northern region adopted zero-burning practices (P9). Of the five principles of the HPRS, tree plantation (Principle 3) and rice cultivation were common in both groups. In particular, food staple species were widely adopted in home gardens. Moreover, there have been several promotions of tree planting development programs to restore northern forests in Thailand [132-134].

Farming knowledge contributed to boosting the overall adoption of the HPRS. The result is consistent with Mishra et al. [98] and Mutyasira et al. [62] who argued that practical knowledge of improved practices, such as integrated farming, tree plantation, home gardening, organic fertilizer, and water regulation in paddy fields contributed to the adoption of improved farming practices. This is also consonant with Kariyasa and Dewi [135] who explained the adoption of improved technologies imparted by the Integrated Crop Management Farmer Field School (ICM-FFS) in Indonesia. Conversely, farmers who had no knowledge and experience in improved techniques were less likely to adopt improved practices brought by extensionists [98]. Education contributed to the adoption, which is consistent with literature showing that educated farmers had a better capacity to access 
information, learn, and understand the benefits of improved farming practices [95-97,114]. As expected, perceived complexity of the HPRS was a deterrent to its adoption. The result was consistent with Rodthong et al. [75], Waseem et al. [77], and Zeweld et al. [43] who found that perceived ease of implementation was a significant predictor of adoption of the range of improved agricultural practices.

Understanding of benefits of the HPRS also contributed to the adoption of and land conversion to the HPRS. It was noted during the discussions with farmers that they had stopped burning maize stover after acknowledging that it caused smog during the dry season, affecting people's heath. Literature also shows that farmers with environmental concerns were more likely to adopt improved farming practices (e.g., crop diversification, organic farming, and soil conservation) $[92,105,106,116,136,137]$. A premium price attracted farmers to opt in for organic farming $[107,138,139]$ while the growing orientation toward food safety among consumers justifies value addition through organic production [140-142]. Pornpratansombat et al. [107], Timprasert et al. [58], and Farrar et al. [106] found that the perception of positive effects on human health and soil conditions led to a greater likelihood of adopting organic farming and IPM for production of vegetables and perennial crops.

Receiving additional training increased the likelihood of land conversion and resulted in implementing more practices in line with the HPRS. The topics of training included the SEP-inspired subjects and improved farming practices (e.g., organic farming, integrated farming, New Theory farming, agroforestry, soil management, and water conservation). The result suggests that frequency of attendance to training enhances knowledge of and familiarity with HPRS practices. Several studies mentioned frequency of formal training as a predictor of improved farming practices adoption [101,108,124].

It was found that the more diverse the water sources, the more the HPRS was adopted. This is consistent with Saiful Islam et al. [76] who found evidence that the availability of irrigation systems influenced the adoption of an integrated rice-fish system. Mango et al. [143] also found that access to irrigation equipment and water sources had positive effects on the adoption of climate-smart practices in Southern Africa.

As expected, participation in workforce sharing was a positive determinant of the overall adoption of the HPRS. Some of the HPRS practices require intensive labor, for example, excavating free-form ponds, digging small contour canals on higher ground, building an embankment, and building check dams. Literature also highlights the labor intensity of some of the improved farming practices, such as organic farming and crop diversification $[116,117,144]$. Additionally, relevant information can be circulated when farmers gather for collective action. Our result is consistent with several studies showing that collective field activities positively influenced the implementation of improved farming practices $[62,92,114]$. In Thailand, traditional agricultural labor exchange is a free-of-charge arrangement that provides immediate returns to households, which is referred to as "Aw Mue Aw Haeng". This is a sort of collective action, which has been practiced for centuries. For instance, two male workers from Farm A go help Farm B harvest rice for one day; later, two male workers from Farm B help Farm A harvest rice or other crops for one day [145].

Farmers with land tenure security were less likely to adopt the HPRS. In general, literature argues that land security is a positive factor for the adoption of improved farming practices, such as crop diversification and agroforestry $[40,99,121]$, which is particularly the case when the sustainable practice requires substantial investment into land resources [146]. On the other hand, land tenure, depending on its type, may restrict land use patterns, especially a major conversion of farmland structure [147]. Moreover, Wannasai and Shrestha [148] found in Thailand that land insecurity could be an incentive to adopt perennial crops, such as fruit trees in a hope to acquire basic land use rights and entitlement to subsequent legal registration, which may explain our findings.

Those with access to advisory were more likely to convert farmland into the HPRS. Some farmers mentioned that advisors provided access to a digging machine and other relevant equipment. Yigezu et al. [78] found in Syria that access to farm equipment significantly facilitated the adoption of zero tillage practices. Some other studies echoed that 
project advisors, extensionists, and trainers were key facilitators of agricultural technology adoption $[60,91,99]$.

Off-farm income had positive effects on the extent of land conversion and the number of HPRS practices implemented. Regular off-farm income, such as salary and remittance, would mitigate the problem of a long wait till reaping benefits in investment systems like the HPRS. Kassie [122] stated that non-farm income was positively related to agroforestry adoption in Ethiopia and that households adopting non-farm activities had less time to take care of seasonal field crops, having shifted land into agroforestry systems. Moreover, off-farm income positively influenced the adoption of improved farming practices in the highlands of Ethiopia [62]. However, Rodthong et al. [75] showed negative influences of off-farm income on the adoption of prescribed sustainable practices for oil palm production.

The tobit estimation showed positive effects of household savings on the extent of land conversion to the HPRS, indicating that lack of savings can be a deterrent. In this relation, lead farmers emphasized that one of the main obstacles to HPRS adoption was the initial investment cost needed to convert farmland. Some farmers asked how long they would have to wait for the investment to reap benefits, while most of the farmers were in need of immediate income. Rodthong et al. [75] found that accumulation of debt discouraged farmers from adopting the set of designated sustainable practices for oil palm production. The District Chief of Mae Cheam, Chiang Mai stated during the meeting that some farmers borrowed money from banks for purchasing farm inputs and later found it difficult to repay, ending up curtailing their expenditure on consumption.

The experience with negative shocks was a deterrent to land conversion to the HPRS, which was in line with literature. Climate hazards were the most agreed impediments that discouraged farmers from adopting new practices. Literature suggests that farmers hesitate to invest in expensive technologies in the presence of climate $[68,125,126]$. For instance, farmers in low rainfall conditions used traditional varieties instead of improved seeds $[68,149]$. Furthermore, Gebremariam and Tesfaye [125] found in rural Ethiopia that production damage and health shocks exerted negative effects on the adoption of costly innovations (e.g., improved seeds and synthetic fertilizer). The non-converters in our study stated that productive land for maize would be wasted in harsh production environments.

Comparing the results from the DHM and the tobit on the extent of land conversion, four variables (i.e., understanding of benefits, land tenure security, negative shocks, and household savings) were significant in the tobit, but not in the DHM. This implies that these four factors were more relevant to the decision to convert farmland than to increasing the proportion of converted land, which was generally agreed on by the first-hurdle results. The triangulation also suggests that all the significant factors identified by the DHM were identified by the tobit model as well. Therefore, the DHM results seem robust not only due to the selection correction through the process with the inverse Mills ratio but also due to the consistency with the alternative model of tobit.

The set of 25 designated practices under the HPRS are intended for conservation of water and soil resources as well as for household consumption of organic rice. Yet not all the practices should be given equal weights, and there should be some prioritization and distinction. First, excavation of a water reservoir is one of the core practices, to which construction of crooked canals, check dams, and small swamps along the canals are complementary practices to support water transportation to agricultural plots. Earth hill building can be optional since soil from the excavated reservoirs is left over in cropland. Second, soil surface cover, such as mulching and ground cover plantation (e.g., vetiver grass, leguminous crops), is another core practice [150], to which application of nutrients into soil is complementary whilst zero burning and zero agrochemicals are optional. Third, organic cultivation of rice and other staple crops is another core practice, which supports food and nutrition security for households. Fruit and long-life trees can be optional for increased food security. Fourth, crop rotation and diversity are another set of core practices, which contributes to soil nutrient management and suppression of pests [151]. Other practices, such as seed conservation, labor sharing, and knowledge sharing are complementary to 
the core practices. On the other hand, construction of water management systems and land preparation involving tillage may disturb soil properties and affect the ecosystems in the long run [150].

\section{Conclusions}

The Hill Pond Rice System (HPRS) has been promoted as an alternative to the intensive and unsustainable maize monocropping with mechanical soil disturbance, especially in the upland areas that have strategic head waters of Thailand. The implementation of the HPRS is expected to restore forest, soil, and water resources that have been degraded due to the intensive applications of tillage and synthetic inputs. Yet, there has been limited quantitative research on the adoption of the HPRS to date. The present article estimated the factors associated with the conversion of farmland into the HPRS, as well as the adoption of the practices designated under the HPRS by collecting primary data from 253 farm households in four provinces (Nan, Chiang Mai, Tak, and Lampang) in northern Thailand and conducting statistical analyses based on the double-hurdle and tobit techniques. While noting a few relatively minor differences, the results were largely consistent across the statistical models employed, where the positive determinants were farming knowledge, understanding of benefits of the HPRS, access to water sources, access to advisory, workforce sharing, off-farm income ratio, additional training, and household savings, whilst the negative determinants were perceived complexity of the HPRS, experiences with negative shocks, and land tenure security. These analytical results underscore the key roles of individual perception of the technologies in question as well as the availability of and access to different types of resources in the adoption of the HPRS.

The empirical findings lead to several policy implications toward the uptake of the HPRS land conversion and the associated techniques. First, there is a need to address the perception of HPRS practices by properly emphasizing the practicality, affordability, and relevance, as a number of the designated practices are indeed familiar to farmers through various previous interventions, such as composting, mulching, soil amendment, traditional water management, homestead livestock rearing, crop diversification, food preservation, and folk handicraft knowledge. Second, the labor constraints in implementation of some of the HPRS practices should be mitigated by promoting on-farm collective action centered around workforce sharing among peer farmers during the peak workload periods. That would be compatible with the small-scale farming systems and can help optimize investment options. Third, meetings between HPRS advisors and farmers should be reinforced for technical exchange and access to relevant equipment.

Lastly, this article has several limitations to be noted. First, the research was conducted in four provinces in northern Thailand. Hence, the findings may not be representative of the whole country or the Southeast Asian region. Second, not all the 25 designated HPRS practices are guaranteed to result in favorable or intended changes in the production environments and natural resource base. As this article focused on the adoption side of the HPRS, ex-post assessment of the environmental, social, and economic impacts of the HPRS was beyond the scope, which would be left to another article. Third, the HPRS is a relatively new system in Thailand. Thus, there is not enough information yet to assess the long-term perspectives of adoption behavior among farmers, such as on the design and mode of the HPRS training needed, and the potential non-adoption of the practices or reverse conversion of farmland.

Author Contributions: Conceptualization: C.S. and T.W.T.; data curation: C.S.; formal analysis: C.S. and T.W.T.; funding acquisition: C.S., T.W.T. and N.S.; investigation: C.S., T.W.T., A.D. and N.S.; methodology: C.S. and T.W.T.; project administration: C.S.; resources: C.S., T.W.T., A.D. and N.S.; software: T.W.T.; supervision, T.W.T., A.D. and N.S.; validation: C.S., T.W.T., A.D. and N.S.; visualization: T.W.T.; writing-original draft: C.S.; writing-review and editing: T.W.T. All authors have read and agreed to the published version of the manuscript. 
Funding: The authors acknowledge open-access publication funding from the UK Research and Innovation's Global Challenges Research Fund (UKRI GCRF) through the Trade, Development, and the Environment Hub project (project number ES/S008160/1) led by the UN Environment Programme World Conservation Monitoring Centre (UNEP-WCMC). The field work was funded by the Ministry of Agriculture and Cooperatives Scholarship and the Asian Institute of Technology Fellowship.

Institutional Review Board Statement: Not applicable.

Informed Consent Statement: Informed consent was obtained from all respondents involved in the study.

Data Availability Statement: The data will be made available upon request to the corresponding author.

Acknowledgments: The authors extend gratitude to the interviewed farmers in northern Thailand, the Lampang Provincial Agricultural Land Reform Office (ALRO), and student assistants from Mae Cheam District, Chiang Mai Province and Mae Ramat District, Tak Province for their assistance during the field work in 2019-2020. Thitimar Chongtaku produced the map in Figure 1.

Conflicts of Interest: The authors declare no conflict of interest.

\section{References}

1. Hazell, P.B.R. The Asian green revolution. Int. Food Policy Res. Inst. 2009, 2, 31.

2. Otsuka, K.; Larson, D.F. (Eds.) An African Green Revolution: Finding Ways to Boost Productivity on Small Farms; Springer Science \& Business Media: Berlin/Heidelberg, Germany, 2013. [CrossRef]

3. Tsusaka, T.; Otsuka, K. The impact of technological changes on crop yields in sub-Saharan Africa, 1967. In An African Green Revolution; Springer Science \& Business Media: Berlin/Heidelberg, Germany, 2013; Volume 9789400757, ISBN 9789400757608.

4. Singh, R.B. Environmental consequences of agricultural development: A case study from the green revolution state of Haryana, India. Agric. Ecosyst. Environ. 2000, 82, 97-103. [CrossRef]

5. Laurance, W.F.; Sayer, J.; Cassman, K.G. Agricultural expansion and its impacts on tropical nature. Trends Ecol. Evol. 2014, 29, 107-116. [CrossRef] [PubMed]

6. Crews-Meyer, K.A. Agricultural landscape change and stability in northeast Thailand: Historical patch-level analysis. Agric. Ecosyst. Environ. 2004, 101, 155-169. [CrossRef]

7. Kanchanaroek, Y.; Aslam, U. Policy schemes for the transition to sustainable agriculture-Farmer preferences and spatial heterogeneity in northern Thailand. Land Use Policy 2018, 78, 227-235. [CrossRef]

8. Vanwambeke, S.O.; Somboon, P.; Lambin, E.F. Rural transformation and land use change in Northern Thailand. J. Land Use Sci. 2007, 2, 1-29. [CrossRef]

9. Sharma, N.; Singhvi, R. Effects of Chemical Fertilizers and Pesticides on Human Health and Environment: A Review. Int. J. Agric. Environ. Biotechnol. 2017, 10, 675. [CrossRef]

10. Attaviroj, P. Soil erosion and land degradation in the northern Thai uplands. In Dryland Management: Economic Case Studies; Dixon, J.A., James, D.E., Sherman, P.B., Eds.; Earthscan/Routledge: London, UK, 1990; Volume 11, ISBN 9781844079636.

11. Bruun, T.B.; de Neergaard, A.; Burup, M.L.; Hepp, C.M.; Larsen, M.N.; Abel, C.; Aumtong, S.; Magid, J.; Mertz, O. Intensification of Upland Agriculture in Thailand: Development or Degradation? Land Degrad. Dev. 2017, 28, 83-94. [CrossRef]

12. Pongkijvorasin, S.; Teerasuwannajak, K.T. Win-Win Solutions for Reforestation and Maize Farming: A Case Study of Nan, Thailand; Elsevier Inc.: Amsterdam, The Netherlands, 2015; ISBN 9780128004166.

13. Munodawafa, A. Assessing nutrient losses with soil erosion under different tillage systems and their implications on water quality. Phys. Chem. Earth 2007, 32, 1135-1140. [CrossRef]

14. Elias, D.; Wang, L.; Jacinthe, P.A. A meta-analysis of pesticide loss in runoff under conventional tillage and no-till management. Environ. Monit. Assess. 2018, 190, 79. [CrossRef]

15. Zhang, Y.; Ma, Q.; Liu, D.; Sun, L.; Ren, X.; Ali, S.; Zhang, P.; Jia, Z. Effects of different fertilizer strategies on soil water utilization and maize yield in the ridge and furrow rainfall harvesting system in semiarid regions of China. Agric. Water Manag. 2018, 208, 414-421. [CrossRef]

16. De Jonge, V.N.; Elliott, M.; Orive, E. Causes, historical development, effects and future challenges of a common environmental problem: Eutrophication. Hydrobiologia 2002, 475-476, 1-19. [CrossRef]

17. Aktar, W.; Sengupta, D.; Chowdhury, A. Impact of pesticides use in agriculture: Their benefits and hazards. Interdiscip. Toxicol. 2009, 2, 1-12. [CrossRef] [PubMed]

18. Savci, S. An Agricultural Pollutant: Chemical Fertilizer. Int. J. Environ. Sci. Dev. 2012, 3, 73-80. [CrossRef]

19. Svensson, O.; Bellamy, A.S.; Van den Brink, P.J.; Tedengren, M.; Gunnarsson, J.S. Assessing the ecological impact of banana farms on water quality using aquatic macroinvertebrate community composition. Environ. Sci. Pollut. Res. 2018, 25, 13373-13381. [CrossRef]

20. Lal, R. Tillage effects on soil degradation, soil resilience, soil quality, and sustainability. Soil Tillage Res. 1993, 27, 1-8. [CrossRef] 
21. Tan, C.S.; Drury, C.F.; Gaynor, J.D.; Welacky, T.W.; Reynolds, W.D. Effect of tillage and water table control on evapotranspiration, surface runoff, tile drainage and soil water content under maize on a clay loam soil. Agric. Water Manag. 2002, 54, 173-188. [CrossRef]

22. Takken, I.; Govers, G.; Jetten, V.; Nachtergaele, J.; Steegen, A.; Poesen, J. Effects of tillage on runoff and erosion patterns. Soil Tillage Res. 2001, 61, 55-60. [CrossRef]

23. McLaughlin, A.; Mineau, P. The impact of agricultural practices on biodiversity. Agric. Ecosyst. Environ. 1995, 55, 201-212. [CrossRef]

24. Houghton, R.A.; House, J.I.; Pongratz, J.; Van Der Werf, G.R.; Defries, R.S.; Hansen, M.C.; Le Quéré, C.; Ramankutty, N. Carbon emissions from land use and land-cover change. Biogeosciences 2012, 9, 5125-5142. [CrossRef]

25. Pitman, A.J.; De Noblet-Ducoudré, N.; Avila, F.B.; Alexander, L.V.; Boisier, J.P.; Brovkin, V.; Delire, C.; Cruz, F.; Donat, M.G.; Gayler, V.; et al. Effects of land cover change on temperature and rainfall extremes in multi-model ensemble simulations. Earth Syst. Dyn. 2012, 3, 213-231. [CrossRef]

26. Thothong, W.; Huon, S.; Janeau, J.L.; Boonsaner, A.; de Rouw, A.; Planchon, O.; Bardoux, G.; Parkpian, P. Impact of land use change and rainfall on sediment and carbon accumulation in a water reservoir of North Thailand. Agric. Ecosyst. Environ. 2011, 140, 521-533. [CrossRef]

27. Wu, J.; Zha, J.; Zhao, D. Estimating the impact of the changes in land use and cover on the surface wind speed over the East China Plain during the period 1980-2011. Clim. Dyn. 2016, 46, 847-863. [CrossRef]

28. Adams, R.M.; Hurd, B.H.; Lenhart, S.; Leary, N. Effects of global climate change on agriculture: An interpretative review. Clim. Res. 1999, 11, 19-30. [CrossRef]

29. Graux, A.I.; Gaurut, M.; Agabriel, J.; Baumont, R.; Delagarde, R.; Delaby, L.; Soussana, J.F. Development of the pasture simulation model for assessing livestock production under climate change. Agric. Ecosyst. Environ. 2011, 144, 69-91. [CrossRef]

30. Tsusaka, T.; Otsuka, K. The declining impacts of climate on crop yields during the green revolution in India, 1972. In An African Green Revolution: Finding Ways to Boost Productivity on Small Farms; Springer Science \& Business Media: Berlin/Heidelberg, Germany, 2013; ISBN 9789400757608.

31. Altieri, M.A. Agroecology: The Science of Sustainable Agriculture; CRC Press: Boca Raton, FL, USA, 2018 ; ISBN 9780429964015.

32. Hobbs, P.R.; Sayre, K.; Gupta, R. The role of conservation agriculture in sustainable agriculture. Philos. Trans. R. Soc. B Biol. Sci. 2008, 363, 543-555. [CrossRef]

33. Pretty, J. The sustainable intensification of agriculture. Nat. Resour. Forum 1997, 21, 247-256. [CrossRef]

34. FAO Conservation Agriculture I Food and Agriculture Organization of the United Nations. Available online: https://www.fao. org/conservation-agriculture/en/ (accessed on 1 December 2021).

35. Gonzalez-Sanchez, E.J.; Veroz-Gonzalez, O.; Blanco-Roldan, G.L.; Marquez-Garcia, F.; Carbonell-Bojollo, R. A renewed view of conservation agriculture and its evolution over the last decade in Spain. Soil Tillage Res. 2015, 146, 204-212. [CrossRef]

36. Abbas, F.; Hammad, H.M.; Fahad, S.; Cerdà, A.; Rizwan, M.; Farhad, W.; Ehsan, S.; Bakhat, H.F. Agroforestry: A sustainable environmental practice for carbon sequestration under the climate change scenarios-A review. Environ. Sci. Pollut. Res. 2017, 24, 11177-11191. [CrossRef]

37. Chartzoulakis, K.; Bertaki, M. Sustainable Water Management in Agriculture under Climate Change. Agric. Agric. Sci. Procedia 2015, 4, 88-98. [CrossRef]

38. Jouzi, Z.; Azadi, H.; Taheri, F.; Zarafshani, K.; Gebrehiwot, K.; Van Passel, S.; Lebailly, P. Organic Farming and Small-Scale Farmers: Main Opportunities and Challenges. Ecol. Econ. 2017, 132, 144-154. [CrossRef]

39. Faucon, M.P.; Houben, D.; Lambers, H. Plant Functional Traits: Soil and Ecosystem Services. Trends Plant Sci. 2017, 22, 385-394. [CrossRef]

40. Nkomoki, W.; Bavorová, M.; Banout, J. Adoption of sustainable agricultural practices and food security threats: Effects of land tenure in Zambia. Land Use Policy 2018, 78, 532-538. [CrossRef]

41. Yin, W.; Chai, Q.; Guo, Y.; Feng, F.; Zhao, C.; Yu, A.; Liu, C.; Fan, Z.; Hu, F.; Chen, G. Reducing carbon emissions and enhancing crop productivity through strip intercropping with improved agricultural practices in an arid area. J. Clean. Prod. 2017, 166, 197-208. [CrossRef]

42. Wezel, A.; Casagrande, M.; Celette, F.; Vian, J.F.; Ferrer, A.; Peigné, J. Agroecological practices for sustainable agriculture. A review. Agron. Sustain. Dev. 2014, 34, 1-20. [CrossRef]

43. Zeweld, W.; Van Huylenbroeck, G.; Tesfay, G.; Speelman, S. Smallholder farmers' behavioural intentions towards sustainable agricultural practices. J. Environ. Manag. 2017, 187, 71-81. [CrossRef]

44. Puntasen, A.; Preedasak, P. Agriculture in Thailand Agriculture the Cross-Road. ASEAN Econ. Bull. 1998, 15, 90-107. [CrossRef]

45. Chouichom, S.; Yamao, M. Comparing opinions and attitudes of organic and non-organic farmers towards organic rice farming system in north-eastern Thailand. J. Org. Syst. 2010, 5, 25-35.

46. Zeng, Z.; Gower, D.B.; Wood, E.F. Accelerating forest loss in Southeast Asian Massif in the 21st century: A case study in Nan Province, Thailand. Glob. Chang. Biol. 2018, 24, 4682-4695. [CrossRef]

47. Du Plessis, J. Maize Production; Department of Agriculture: Pretoria, South Africa, 2003; pp. 1-38.

48. Bergier, I. Effects of highland land-use over lowlands of the Brazilian Pantanal. Sci. Total Environ. 2013, 463-464, 1060-1066. [CrossRef] 
49. Jitsanguan, T. Sustainable Agricultural Systems for Small-Scale Farmers in Thailand: Implications for the Environment; Food and Fertilizer Technology Center: Kawana, Japan, 2001; pp. 1-11.

50. NESCB. The Twelfth National Economic and Social Development Plan (2017-2021); NESCB: Bangkok, Thailand, 2017.

51. Salaisook, P.; Faysse, N.; Tsusaka, T.W. Reasons for adoption of sustainable land management practices in a changing context: A mixed approach in Thailand. Land Use Policy 2020, 96, 104676. [CrossRef]

52. Bangkok Post. Royal Farming Model off to Running Start. Available online: https://www.bangkokpost.com/thailand/general/ 1992531/royal-farming-model-off-to-running-start (accessed on 1 December 2021).

53. UNDP. Thailand Human Development Report 2007, Sufficiency Economy and Human Development; UNDP: New York, NY, USA, 2007; ISBN 974-88126-3-4.

54. Salyakamthorn, W. The ground work solution: Learning strategies toward self-reliance in asia. In Indigenous Culture, Education and Globalization: Critical Perspectives from Asia; Springer: Berlin/Heidelberg, Germany, 2016; ISBN 9783662481592.

55. Kerdsriserm, C.; Suwanmaneepong, S.; Mankeb, P. Factors affecting adoption of organic rice farming in sustainable agriculture network, Chachoengsao Province, Thailand. Int. J. Agric. Technol. 2016, 12, 1229-1239.

56. Thapa, G.B.; Rattanasuteerakul, K. Adoption and extent of organic vegetable farming in Mahasarakham province, Thailand. Appl. Geogr. 2011, 31, 201-209. [CrossRef]

57. Jierwiriyapant, P.; Liangphansakul, O.A.; Chulaphun, W.; Pichaya-satrapongs, T. Factors affecting organic rice production adoption of farmers in Northern Thailand. Chiang Mai Univ. J. Nat. Sci. 2012, 11, 327-333.

58. Timprasert, S.; Datta, A.; Ranamukhaarachchi, S.L. Factors determining adoption of integrated pest management by vegetable growers in Nakhon Ratchasima Province, Thailand. Crop Prot. 2014, 62, 32-39. [CrossRef]

59. Asfaw, D.; Neka, M. Factors affecting adoption of soil and water conservation practices: The case of Wereillu Woreda (District), South Wollo Zone, Amhara Region, Ethiopia. Int. Soil Water Conserv. Res. 2017, 5, 273-279. [CrossRef]

60. Belachew, A.; Mekuria, W.; Nachimuthu, K. Factors influencing adoption of soil and water conservation practices in the northwest Ethiopian highlands. Int. Soil Water Conserv. Res. 2020, 8, 80-89. [CrossRef]

61. Jones, S. A framework for understanding on-farm environmental degradation and constraints to the adoption of soil conservation measures: Case studies from Highland Tanzania and Thailand. World Dev. 2002, 30, 1607-1620. [CrossRef]

62. Mutyasira, V.; Hoag, D.; Pendell, D. The adoption of sustainable agricultural practices by smallholder farmers in Ethiopian highlands: An integrative approach. Cogent Food Agric. 2018, 4, 1552439. [CrossRef]

63. Saint-Macary, C.; Keil, A.; Zeller, M.; Heidhues, F.; Dung, P.T.M. Land titling policy and soil conservation in the northern uplands of Vietnam. Land Use Policy 2010, 27, 617-627. [CrossRef]

64. Abeje, M.T.; Tsunekawa, A.; Adgo, E.; Haregeweyn, N.; Nigussie, Z.; Ayalew, Z.; Elias, A.; Molla, D.; Berihun, D. Exploring drivers of livelihood diversification and its effect on adoption of sustainable land management practices in the upper Blue Nile basin, Ethiopia. Sustainability 2019, 11, 2991. [CrossRef]

65. Jara-Rojas, R.; Russy, S.; Roco, L.; Fleming-Muñoz, D.; Engler, A. Factors affecting the adoption of agroforestry practices: Insights from silvopastoral systems of Colombia. Forests 2020, 11, 648. [CrossRef]

66. Lapar, M.L.A.; Ehui, S.K. Factors affecting adoption of dual-purpose forages in the Philippine uplands. Agric. Syst. 2004, 81, 95-114. [CrossRef]

67. Pham, H.G.; Chuah, S.H.; Feeny, S. Factors affecting the adoption of sustainable agricultural practices: Findings from panel data for Vietnam. Ecol. Econ. 2021, 184, 107000. [CrossRef]

68. Kassie, M.; Jaleta, M.; Shiferaw, B.; Mmbando, F.; Mekuria, M. Adoption of interrelated sustainable agricultural practices in smallholder systems: Evidence from rural Tanzania. Technol. Forecast. Soc. Chang. 2013, 80, 525-540. [CrossRef]

69. Teklewold, H.; Kassie, M.; Shiferaw, B.; Köhlin, G. Cropping system diversification, conservation tillage and modern seed adoption in Ethiopia: Impacts on household income, agrochemical use and demand for labor. Ecol. Econ. 2013, 93, 85-93. [CrossRef]

70. Liu, H.; Huang, Q. Adoption and continued use of contour cultivation in the highlands of southwest China. Ecol. Econ. 2013, 91, 28-37. [CrossRef]

71. Yap, V.Y.; de Neergaard, A.; Bruun, T.B. ‘To Adopt or not to Adopt?' Legume Adoption in Maize-Based Systems of Northern Thailand: Constraints and Potentials. Land Degrad. Dev. 2017, 28, 731-741. [CrossRef]

72. Chongtaku, T. Generated the Map Only for This Paper, Using ArcGIS for Desktop Advanced; Version 10.7.1.; Esri: Redlands, CA, USA, 2021.

73. DFID. Sustainable Livelihoods Guidance Sheets; Department for International Development: London, UK, 2000.

74. Chalak, A.; Irani, A.; Chaaban, J.; Bashour, I.; Seyfert, K.; Smoot, K.; Abebe, G.K. Farmers' Willingness to Adopt Conservation Agriculture: New Evidence from Lebanon. Environ. Manag. 2017, 60, 693-704. [CrossRef]

75. Rodthong, W.; Kuwornu, J.K.M.; Datta, A.; Anal, A.K.; Tsusaka, T.W. Factors Influencing the Intensity of Adoption of the Roundtable on Sustainable Palm Oil Practices by Smallholder Farmers in Thailand. Environ. Manag. 2020, 66, 377-394. [CrossRef]

76. Saiful Islam, A.H.M.; Barman, B.K.; Murshed-e-Jahan, K. Adoption and impact of integrated rice-fish farming system in Bangladesh. Aquaculture 2015, 447, 76-85. [CrossRef]

77. Waseem, R.; Mwalupaso, G.E.; Waseem, F.; Khan, H.; Panhwar, G.M.; Shi, Y. Adoption of sustainable agriculture practices in banana farm production: A study from the Sindh Region of Pakistan. Int. J. Environ. Res. Public Health 2020, 17, 3714. [CrossRef] 
78. Yigezu, Y.A.; Mugera, A.; El-Shater, T.; Aw-Hassan, A.; Piggin, C.; Haddad, A.; Khalil, Y.; Loss, S. Enhancing adoption of agricultural technologies requiring high initial investment among smallholders. Technol. Forecast. Soc. Change 2018, 134, 199-206. [CrossRef]

79. Tobin, J. Estimation of Relationships for Limited Dependent Variables. Econometrica 1958, 26, 24-36. [CrossRef]

80. Greene, W. Marginal effects in the censored regression model. Econ. Lett. 1999, 64, 43-49. [CrossRef]

81. McDonald, J.F.; Moffitt, R.A. The Uses of Tobit Analysis. Rev. Econ. Stat. 1980, 62, 318-321. [CrossRef]

82. Cragg, J.G. Some Statistical Models for Limited Dependent Variables with Application to the Demand for Durable Goods. Econometrica 1971, 39, 829-844. [CrossRef]

83. Srisawasdi, W.; Tsusaka, T.W.; Winijkul, E.; Sasaki, N. Valuation of local demand for improved air quality: The case of the mae moh coal mine site in thailand. Atmosphere 2021, 12, 1132. [CrossRef]

84. Kunzekweguta, M.; Rich, K.M.; Lyne, M.C. Factors affecting adoption and intensity of conservation agriculture techniques applied by smallholders in Masvingo district, Zimbabwe. Agrekon 2017, 56, 330-346. [CrossRef]

85. Chen, L.; Guan, X.; Zhuo, J.; Han, H.; Gasper, M.; Doan, B.; Yang, J.; Ko, T.H. Application of Double Hurdle Model on Effects of Demographics for Tea Consumption in China. J. Food Qual. 2020, 2020, 9862390. [CrossRef]

86. StataCorp. Stata Statistical Software: Release 17; StataCorp LLCCollege: Station, TX, USA, 2021.

87. Métouolé Méda, Y.J.; Egyir, I.S.; Zahonogo, P.; Jatoe, J.B.D.; Atewamba, C. Institutional factors and farmers' adoption of conventional, organic and genetically modified cotton in Burkina Faso. Int. J. Agric. Sustain. 2018, 16, 40-53. [CrossRef]

88. Ndiritu, S.W.; Kassie, M.; Shiferaw, B. Are there systematic gender differences in the adoption of sustainable agricultural intensification practices? Evidence from Kenya. Food Policy 2014, 49, 117-127. [CrossRef]

89. Beshir, H. Factors Affecting the Adoption and Intensity of Use of Improved Forages in North East Highlands of Ethiopia. Am. J. Exp. Agric. 2014, 4, 12-27. [CrossRef]

90. Nigussie, Z.; Tsunekawa, A.; Haregeweyn, N.; Adgo, E.; Nohmi, M.; Tsubo, M.; Aklog, D.; Meshesha, D.T.; Abele, S. Factors influencing small-scale farmers' adoption of sustainable land management technologies in north-western Ethiopia. Land Use Policy 2017, 67, 57-64. [CrossRef]

91. Kabir, M.H.; Rainis, R. Adoption and intensity of integrated pest management (IPM) vegetable farming in Bangladesh: An approach to sustainable agricultural development. Environ. Dev. Sustain. 2015, 17, 1413-1429. [CrossRef]

92. Wollni, M.; Andersson, C. Spatial patterns of organic agriculture adoption: Evidence from Honduras. Ecol. Econ. 2014, 97, 120-128. [CrossRef]

93. Azam, S.; Banumathi, M. The Role of Demographic Factors in Adopting Organic Farming: A Logistic Model Approach. Int. J. Adv. Res. 2015, 3, 713-720.

94. Teshome, A.; de Graaff, J.; Kassie, M. Household-Level Determinants of Soil and Water Conservation Adoption Phases: Evidence from North-Western Ethiopian Highlands. Environ. Manag. 2016, 57, 620-636. [CrossRef]

95. Pinthukas, N. Farmers' Perception and Adaptation in Organic Vegetable Production for Sustainable Livelihood in Chiang Mai Province. Agric. Agric. Sci. Procedia 2015, 5, 46-51. [CrossRef]

96. Ma, W.; Ma, C.; Su, Y.; Nie, Z. Organic farming: Does acquisition of the farming information influence Chinese apple farmers willingness to adopt? China Agric. Econ. Rev. 2017, 9, 211-224. [CrossRef]

97. Ntshangase, N.L.; Muroyiwa, B.; Sibanda, M. Farmers' perceptions and factors influencing the adoption of no-till conservation agriculture by small-scale farmers in Zashuke, KwaZulu-Natal province. Sustainability 2018, 10, 555. [CrossRef]

98. Mishra, B.; Gyawali, B.R.; Paudel, K.P.; Poudyal, N.C.; Simon, M.F.; Dasgupta, S.; Antonious, G. Adoption of Sustainable Agriculture Practices among Farmers in Kentucky, USA. Environ. Manag. 2018, 62, 1060-1072. [CrossRef] [PubMed]

99. Kassie, M.; Teklewold, H.; Jaleta, M.; Marenya, P.; Erenstein, O. Understanding the adoption of a portfolio of sustainable intensification practices in eastern and southern Africa. Land Use Policy 2015, 42, 400-411. [CrossRef]

100. Mozzato, D.; Gatto, P.; Defrancesco, E.; Bortolini, L.; Pirotti, F.; Pisani, E.; Sartori, L. The role of factors affecting the adoption of environmentally friendly farming practices: Can geographical context and time explain the differences emerging from literature? Sustainability 2018, 10, 3101. [CrossRef]

101. Muriithi, B.W.; Gathogo, N.G.; Diiro, G.M.; Mohamed, S.A.; Ekesi, S. Potential adoption of integrated pest management strategy for suppression of mango fruit flies in East Africa: An ex ante and ex post analysis in Ethiopia and Kenya. Agriculture 2020, 10, 278. [CrossRef]

102. Ng'ombe, J.; Kalinda, T.; Tembo, G.; Kuntashula, E. Econometric analysis of the factors that affect adoption of conservation farming practices by smallholder farmers in Zambia. J. Sustain. Dev. 2014, 7, 124-138. [CrossRef]

103. Kallas, Z.; Serra, T.; Gil, J.M. Farmer's Objectives as Determinant Factors for Organic Farming Adoption: The Case of Catalonia Vineyard Production. Agric. Econ. 2010, 41, 409-423. [CrossRef]

104. Läpple, D.; Kelley, H. Understanding the uptake of organic farming: Accounting for heterogeneities among Irish farmers. Ecol. Econ. 2013, 88, 11-19. [CrossRef]

105. Micha, E.; Areal, F.J.; Tranter, R.B.; Bailey, A.P. Uptake of agri-environmental schemes in the Less-Favoured Areas of Greece: The role of corruption and farmers' responses to the financial crisis. Land Use Policy 2015, 48, 144-157. [CrossRef]

106. Farrar, J.J.; Baur, M.E.; Elliott, S.F. Adoption of IPM practices in grape, tree fruit, and nut production in the Western United States. J. Integr. Pest Manag. 2016, 7. [CrossRef] 
107. Pornpratansombat, P.; Bauer, B.; Boland, H. The adoption of organic rice farming in Northeastern Thailand. J. Org. Syst. 2011, 6, 4-12.

108. Cafer, A.M.; Rikoon, J.S. Adoption of new technologies by smallholder farmers: The contributions of extension, research institutes, cooperatives, and access to cash for improving tef production in Ethiopia. Agric. Human Values 2018, 35, 685-699. [CrossRef]

109. Nakano, Y.; Tsusaka, T.W.; Aida, T.; Pede, V.O. Is farmer-to-farmer extension effective? The impact of training on technology adoption and rice farming productivity in Tanzania. World Dev. 2018, 105, 336-351. [CrossRef]

110. Gil, J.; Siebold, M.; Berger, T. Adoption and development of integrated crop-livestock-forestry systems in Mato Grosso, Brazil. Agric. Ecosyst. Environ. 2015, 199, 394-406. [CrossRef]

111. Okon, U.E.; Idiong, I.C. Factors Influencing Adoption of Organic Vegetable Farming among Farm Households in South-South Region of Nigeria. Am. J. Agric. Environ. Sci. 2016, 16, 852-859. [CrossRef]

112. Salazar, C.; Rand, J. Production risk and adoption of irrigation technology: Evidence from small-scale farmers in Chile. Lat. Am. Econ. Rev. 2016, 25, 2. [CrossRef]

113. Makate, C.; Makate, M.; Mango, N. Sustainable agriculture practices and livelihoods in pro-poor smallholder farming systems in southern Africa. Afr. J. Sci. Technol. Innov. Dev. 2017, 9, 269-279. [CrossRef]

114. Ma, W.; Abdulai, A. IPM adoption, cooperative membership and farm economic performance: Insight from apple farmers in China. China Agric. Econ. Rev. 2019, 11, 218-236. [CrossRef]

115. de Graaff, J.; Amsalu, A.; Bodnár, F.; Kessler, A.; Posthumus, H.; Tenge, A. Factors influencing adoption and continued use of long-term soil and water conservation measures in five developing countries. Appl. Geogr. 2008, 28, 271-280. [CrossRef]

116. Kasem, S.; Thapa, G.B. Crop diversification in Thailand: Status, determinants, and effects on income and use of inputs. Land Use Policy 2011, 28, 618-628. [CrossRef]

117. Mendoza, T.C. Evaluating the benefits of organic farming in rice agroecosystems in the Philippines. J. Sustain. Agric. 2004, 24, 93-115. [CrossRef]

118. Schneeberger, W.; Darnhofer, I.; Eder, M. Barriers to the adoption of organic farming by cash-crop producers in Austria. Artic. Am. J. Altern. Agric. 2002, 17, 24-31. [CrossRef]

119. Rajendran, N.; Tey, Y.S.; Brindal, M.; Ahmad Sidique, S.F.; Shamsudin, M.N.; Radam, A.; Abdul Hadi, A.H.I. Factors influencing the adoption of bundled sustainable agricultural practices: A systematic literature review. Int. Food Res. J. 2016, 23, 2271-2279.

120. Abdulai, A.; Owusu, V.; Goetz, R. Land tenure differences and investment in land improvement measures: Theoretical and empirical analyses. J. Dev. Econ. 2011, 96, 66-78. [CrossRef]

121. Fouladbash, L.; Currie, W.S. Agroforestry in Liberia: Household practices, perceptions and livelihood benefits. Agrofor. Syst. 2015, 89, 247-266. [CrossRef]

122. Kassie, G.W. Agroforestry and farm income diversification: Synergy or trade-off? The case of Ethiopia. Environ. Syst. Res. 2018, 6, 8. [CrossRef]

123. Arslan, A.; Belotti, F.; Lipper, L. Smallholder productivity and weather shocks: Adoption and impact of widely promoted agricultural practices in Tanzania. Food Policy 2017, 69, 68-81. [CrossRef]

124. Darkwah, K.A.; Kwawu, J.D.; Agyire-Tettey, F.; Sarpong, D.B. Assessment of the determinants that influence the adoption of sustainable soil and water conservation practices in Techiman Municipality of Ghana. Int. Soil Water Conserv. Res. 2019, 7, $248-257$. [CrossRef]

125. Gebremariam, G.; Tesfaye, W. The heterogeneous effect of shocks on agricultural innovations adoption: Microeconometric evidence from rural Ethiopia. Food Policy 2018, 74, 154-161. [CrossRef]

126. Lefebvre, M.; Midler, E.; Bontems, P. Adoption of Environment-Friendly Agricultural Practices with Background Risk: Experimental Evidence. Environ. Resour. Econ. 2020, 76, 405-428. [CrossRef]

127. Mango, N.; Makate, C.; Tamene, L.; Mponela, P.; Ndengu, G. Adoption of small-scale irrigation farming as a climate-smart agriculture practice and its influence on household income in the Chinyanja Triangle, Southern Africa. Land 2018, 7, 49. [CrossRef]

128. Makate, C.; Wang, R.; Makate, M.; Mango, N. Crop diversification and livelihoods of smallholder farmers in Zimbabwe: Adaptive management for environmental change. Springerplus 2016, 5, 1135. [CrossRef] [PubMed]

129. NSO. The 2019 Household Socio-Economic Survey of Whole Kingdom of Thailand. National Statistical Office. Ministry of Digital Economy and Society; NSO: Bangkok, Thailand, 2020.

130. Office of Agricultural Economics (OAE). Agiculteral Statistics of Thailand 2019; OAE: Bangkok, Thailand, 2019.

131. Mostafanezhad, M.; Evrard, O. Chronopolitics of crisis: A historical political ecology of seasonal air pollution in northern Thailand. Geoforum 2021, 124, 400-408. [CrossRef]

132. Elliott, S.; Chairuangsri, S.; Kuaraksa, C.; Sangkum, S.; Sinhaseni, K.; Shannon, D.; Nippanon, P.; Manohan, B. Collaboration and conflict-developing forest restoration techniques for Northern Thailand's upper watersheds whilst meeting the needs of science and communities. Forests 2019, 10, 732. [CrossRef]

133. Limnirankul, B.; Onprapai, T.; Gypmantasiri, P. Building Local Capacities in Natural Resources Management for Food Security in the Highlands of Northern Thailand. Agric. Agric. Sci. Procedia 2015, 5, 30-37. [CrossRef]

134. Sangsupan, H.A.; Hibbs, D.E.; Withrow-Robinson, B.A.; Elliott, S. Seed and microsite limitations of large-seeded, zoochorous trees in tropical forest restoration plantations in northern Thailand. For. Ecol. Manag. 2018, 419-420, 91-100. [CrossRef]

135. Kariyasa, K.; Dewi, Y.A. Analysis of Factors Affecting Adoption of Integrated Crop Management Farmer Field School (ICM-FFS) in Swampy Areas. Int. J. Food Agric. Econ. 2013, 1, 29-38. 
136. Läpple, D.; Rensburg, T. Van Adoption of organic farming: Are there differences between early and late adoption? Ecol. Econ. 2011, 70, 1406-1414. [CrossRef]

137. Mzoughi, N. Do organic farmers feel happier than conventional ones? An exploratory analysis. Ecol. Econ. 2014, 103, 38-43. [CrossRef]

138. Bravo-Monroy, L.; Potts, S.G.; Tzanopoulos, J. Drivers influencing farmer decisions for adopting organic or conventional coffee management practices. Food Policy 2016, 58, 49-61. [CrossRef]

139. Parvathi, P.; Waibel, H. Organic Agriculture and Fair Trade: A Happy Marriage? A Case Study of Certified Smallholder Black Pepper Farmers in India. World Dev. 2016, 77, 206-220. [CrossRef]

140. Adams, D.C.; Salois, M.J. Local versus organic: A turn in consumer preferences and willingness-to-pay. Renew. Agric. Food Syst. 2010, 25, 331-341. [CrossRef]

141. Essoussi, L.H.; Zahaf, M. Exploring the decision-making process of Canadian organic food consumers: Motivations and trust issues. Qual. Mark. Res. 2009, 12, 443-459. [CrossRef]

142. Sangkumchaliang, P.; Huang, W.C. Consumers' perceptions and attitudes of organic food products in northern thailand. Int. Food Agribus. Manag. Rev. 2012, 15, 87-102. [CrossRef]

143. Mango, N.; Makate, C.; Mapemba, L.; Sopo, M. The role of crop diversification in improving household food security in central Malawi. Agric. Food Secur. 2018, 7, 7. [CrossRef]

144. Adebiyi, J.A.; Olabisi, L.S.; Richardson, R.; Liverpool-Tasie, L.S.O.; Delate, K. Drivers and constraints to the adoption of organic leafy vegetable production in Nigeria: A livelihood approach. Sustainability 2020, 12, 96. [CrossRef]

145. Hongladarom, C. Labor Contracts in Thai Agriculture: A Preliminary Investigation (No. 84); Thammasat University, Faculty of Economics: Phra Nakhon, Thailand, 1981.

146. Chunhabunyatip, P.; Sasaki, N.; Grünbühel, C.; Kuwornu, J.K.M.; Tsusaka, T.W. Influence of indigenous spiritual beliefs on natural resource management and ecological conservation in Thailand. Sustainability 2018, 10, 2842. [CrossRef]

147. Routray, J.K.; Sahoo, M. Implications of land title for farm credit in Thailand. Land Use Policy 1995, 12, 86-89. [CrossRef]

148. Wannasai, N.; Shrestha, R.P. Role of land tenure security and farm household characteristics on land use change in the Prasae Watershed, Thailand. Land Use Policy 2008, 25, 214-224. [CrossRef]

149. Ho, T.D.N.; Tsusaka, T.W.; Kuwornu, J.K.M.; Datta, A.; Nguyen, L.T. Do rice varieties matter? Climate change adaptation and livelihood diversification among rural smallholder households in the Mekong Delta Region of Vietnam. Mitig. Adapt. Strateg. Glob. Chang. 2022, 27, 8. [CrossRef]

150. Donjadee, S.; Tingsanchali, T. Soil and water conservation on steep slopes by mulching using rice straw and vetiver grass clippings. Agric. Nat. Resour. 2016, 50, 75-79. [CrossRef]

151. Letourneau, D.K.; Armbrecht, I.; Rivera, B.S.; Lerma, J.; Carmona, E.J.; Daza, M.C.; Escobar, S.; Galindo, V.; GutiéRrez, C.; LóPez, S.D.; et al. Does plant diversity benefit agroecosystems? A synthetic review. Ecol. Appl. 2011, 21, 9-21. [CrossRef] 